\title{
The small heterodimer partner is a gonadal gatekeeper of sexual maturation in male mice
}

\author{
David H. Volle, ${ }^{1}$ Rajesha Duggavathi, ${ }^{1}$ Benjamin C. Magnier, ${ }^{1}$ Sander M. Houten, ${ }^{1}$ \\ Carolyn L. Cummins, ${ }^{2}$ Jean-Marc A. Lobaccaro, ${ }^{3}$ Guido Verhoeven, ${ }^{4}$ Kristina Schoonjans, ${ }^{1}$ and \\ Johan Auwerx 1,5,6,7 \\ ${ }^{1}$ Institut de Génétique et de Biologie Moléculaire et Cellulaire (IGBMC), Centre National de la Recherche Scientifique \\ (CNRS)/Institut National de la Santé et de la Recherche Médicale (INSERM)/Université Louis Pasteur (ULP), 67404 Illkirch, \\ France; ${ }^{2}$ Department of Pharmacology and Howard Hughes Medical Institute, University of Texas Southwestern Medical \\ Center, Dallas, Texas 75390, USA; ${ }^{3}$ Laboratoire de Physiologie Comparée et Endocrinologie Moléculaire, UMR CNRS 6547, \\ 63177 Aubière, France; ${ }^{4}$ Laboratory for Experimental Medecine and Endocrinology, Katholieke Universiteit Leuven, B-3000 \\ Leuven, Belgium; ${ }^{5}$ Institut Clinique de la Souris (ICS), 67404 Illkirch, France; ${ }^{6}$ Hôpitaux Universitaires de Strasbourg, \\ Laboratoire de Biochimie Générale et Spécialisée, 67000 Strasbourg, France
}

\begin{abstract}
The small heterodimer partner (SHP) is an atypical nuclear receptor known mainly for its role in bile acid homeostasis in the enterohepatic tract. We explore here the role of SHP in the testis. SHP is expressed in the interstitial compartment of the adult testes, which contain the Leydig cells. SHP there inhibits the expression of steroidogenic genes, on the one hand by inhibiting the expression of the nuclear receptors steroidogenic factor-1 and liver receptor homolog-1 (lrh-1), and on the other hand by directly repressing the transcriptional activity of LRH-1. Consequently, in SHP knockout mice, testicular testosterone synthesis is increased independently of the hypothalamus-pituitary axis. Independent of its action on androgen synthesis, SHP also determines the timing of germ cell differentiation by controlling testicular retinoic acid metabolism. Through the inhibition of the transcriptional activity of retinoic acid receptors, SHP controls the expression of stimulated by retinoic acid gene 8 (stra8) - a gene that is indispensable for germ cell meiosis and differentiation. Together, our data demonstrate new roles for SHP in testicular androgen and retinoic acid metabolism, making SHP a testicular gatekeeper of the timing of male sexual maturation.
\end{abstract}

[Keywords: Farnesoid X receptor; germ cell differentiation; liver receptor homolog-1; retinoic acid receptor; steroidogenesis; testis]

Supplemental material is available at http://www.genesdev.org.

Received September 11, 2006; revised version accepted December 21, 2006.

Male fertility is controlled by complex interactions among the hypothalamus, pituitary, and testis. The major functions of the testis include production of male gametes and secretion of testosterone. Testosterone synthesized by the testicular Leydig cells is responsible for the development of testes, the attainment of puberty, and the maintenance of spermatogenesis, secondary sexual characteristics, and fertility (Wilson et al. 2002). Spermatogenesis takes place within the seminiferous tubules in association with the Sertoli cells, which provide structural and nutritional support for the developing germ cells. Coordinated regulation of mitosis and meiosis underpins normal spermatogenesis. However, mecha-

${ }^{7}$ Corresponding author.

E-MAIL auwerx@igbmc.u-strasbg.fr; FAX 33-3-88653201.

Article is online at http://www.genesdev.org/cgi/doi/10.1101/gad.409307. nisms involved in the testicular steroidogenesis and germ cell differentiation that are the hallmarks of male fertility are not completely understood.

Nuclear receptors (NRs) are a family of transcription factors with a conserved modular structure (Giguere 1999) that control a plethora of cellular functions, including steroidogenesis (Beuschlein et al. 2002; Francis et al. 2003; Shibata et al. 2003; Fayard et al. 2004), puberty (Murphy et al. 1994; Hiort 2002), and cell cycle (Fu et al. 2003; Botrugno et al. 2004). The two members of the NR5A subfamily of NRs - the steroidogenic factor 1 (SF-1, NR5A1) and the liver receptor homolog 1 (LRH-1, NR5A2)-have been shown to control the transcription of many genes involved in steroidogenesis (Bakke et al. 2001; Kim et al. 2004, 2005; Mueller et al. 2006). While deletion of SF-1 in the steroidogenic Leydig cells results in infertility in male mice primarily driven by an abnormal testicular descent (Jeyasuria et al. 2004), the role of 
Volle et al.

LRH-1 in the Leydig cells of the testis remains elusive (Pezzi et al. 2004).

The small heterodimer partner (SHP, NROB2) is an atypical NR that lacks a DNA-binding domain, and together with the dosage-sensitive sex reversal-adrenal hypoplasia congenita gene on the $\mathrm{X}$ chromosome, gene 1 (Dax-1, NR0B1), it constitutes the NR0B subfamily (Seol et al. 1996). SHP is mainly known for its role in the liver, where it is involved in the feedback inhibition of bile acid synthesis (Goodwin et al. 2000; Lu et al. 2000; Kerr et al. 2002; Wang et al. 2002). This function of SHP has been linked to its ability to repress the transcriptional activity of other NRs such as LRH-1 (Goodwin et al. 2000; Lu et al. 2000). In addition to the liver, SHP has also been shown to be expressed at lower levels in the testis (Johansson et al. 1999; Lu et al. 2001), but its exact role in this tissue still needs to be defined.

Using both genetic and pharmacologic strategies in the mouse, we show here that SHP deficiency results in an early rise in fertility as a result of removal of the repressive effects of SHP on genes involved in the testicular steroidogenesis and on the retinoic acid (RA)-regulated genes involved in germ cell differentiation in the testis.

\section{Results}

SHP deficiency leads to higher testosterone levels

To elucidate the role of SHP in the testis, we analyzed both plasma and intratesticular concentrations of testos- terone in control floxed $\left(\mathrm{SHP}^{\mathrm{L} 2 / \mathrm{L} 2}\right)$ and SHP knockout $\left(\mathrm{SHP}^{\mathrm{L}-/ \mathrm{L}-}\right)$ mice. Both plasma (Fig. 1A) and intratesticular (data not shown) concentrations of testosterone were significantly higher in $\mathrm{SHP}^{\mathrm{L}-/ \mathrm{L}-}$ mice. The testicular mRNA expression of steroidogenic genes-including the steroidogenic acute regulatory protein (star), cytochrome P450 side-chain cleavage (cyp11a1), and 3 $\beta$-hydroxysteroid dehydrogenase $(3 \beta-h s d)$-was higher in $\mathrm{SHP}^{\mathrm{L}-/ \mathrm{L}-}$ compared with $\mathrm{SHP}^{\mathrm{L} 2 / \mathrm{L} 2}$ mice (Fig. 1B). There was, however, no difference in the expression of cytochrome P450 $17 \alpha$ hydroxylase (cyp17) between the two genotypes.

Phenotypically, 12-wk-old adult SHP $\mathrm{L}^{\mathrm{L}-\mathrm{L}-}$ and $\mathrm{SHP}^{\mathrm{L} 2 / \mathrm{L} 2}$ males were similar in terms of body, liver, and spleen weights (Fig. 1C). However, SHP ${ }^{\mathrm{L}-/ \mathrm{L}-}$ males showed several differences in the reproductive organs compared with $\mathrm{SHP}^{\mathrm{L} 2 / \mathrm{L} 2}$ mice. The epididymidal weight was $17 \%$ higher in $\mathrm{SHP}^{\mathrm{L}-/ \mathrm{L}-}$ mice (Fig. $1 \mathrm{C}$ ). $\mathrm{SHP}^{\mathrm{L}-/ \mathrm{L}-}$ mice also had a tendency to have heavier seminal vesicles than $\mathrm{SHP}^{\mathrm{L} 2 / \mathrm{L} 2}$ mice (Fig. $1 \mathrm{C}$ ). These results are consistent with the known effect of androgens (Wilson et al. 2002). In contrast, the testes were smaller and weighed $20 \%$ less in the SHP ${ }^{\mathrm{L}-/ \mathrm{L}-}$ mice (Fig. 1C).

Although these results indicated that SHP is involved in the regulation of testosterone synthesis, they did not allow us to identify whether these effects were centrally or locally mediated. To address this question, we examined the plasma level of luteinizing hormone (LH) and mRNA expression of luteinizing hormone $\beta(1 \mathrm{hb})$ in the pituitary. Although Lhb mRNA levels were lower in the pituitary of $\mathrm{SHP}^{\mathrm{L}-/ \mathrm{L}-}$, this seemingly did not affect
A

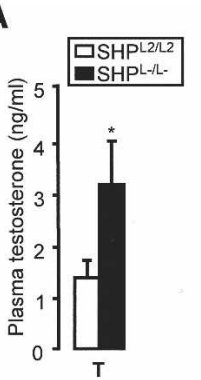

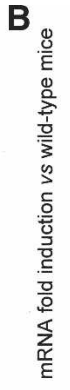

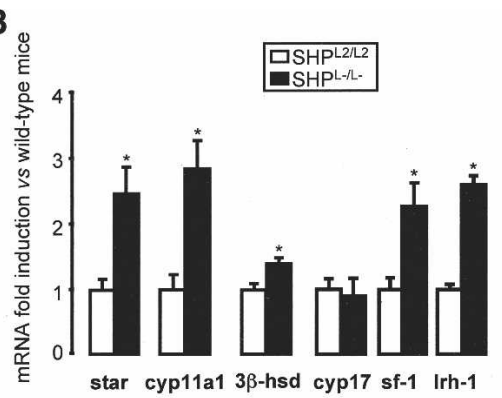

C
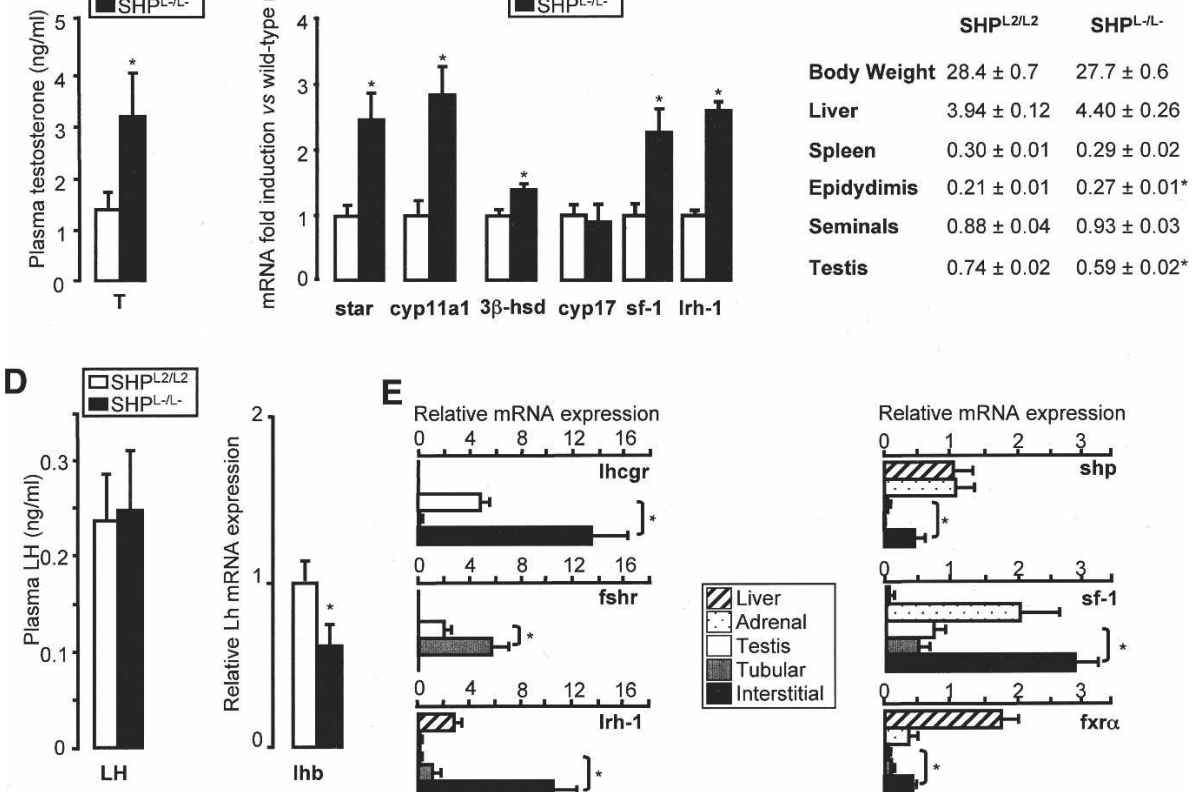

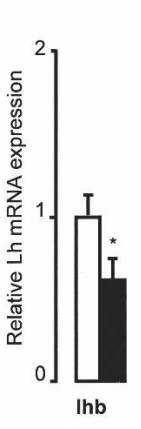

$\mathbf{E}$

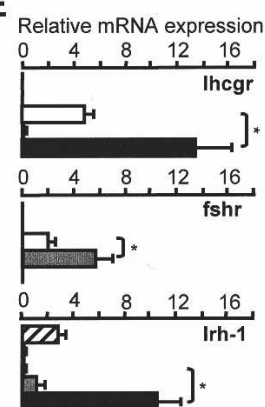

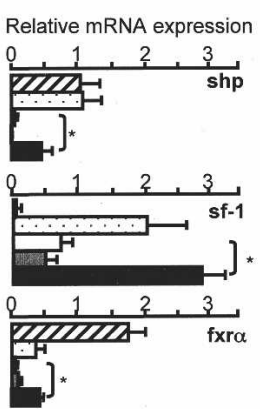

Figure 1. SHP deficiency leads to hypertestosteronemia. (A) Plasma testosterone levels in SHP $\mathrm{L}^{\mathrm{L} / \mathrm{L} 2}$ and $\mathrm{SHP} \mathrm{L}^{\mathrm{L}-/ \mathrm{L}-}$ mice $(n=10-15$ per

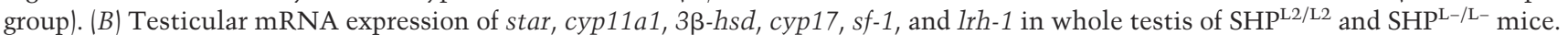
(C) Weights of liver, spleen, testis, epididymides, and seminal vesicles normalized to body weight in $\mathrm{SHP}^{\mathrm{L} 2 / \mathrm{L} 2}$ and $\mathrm{SHP} \mathrm{P}^{\mathrm{L}-/ \mathrm{L}-} \mathrm{mice}\left({ }^{\star}\right)$ $p<0.05$. (D) Plasma LH and pituitary mRNA expression of $1 \mathrm{hb}$ in SHP ${ }^{\mathrm{L} 2 / \mathrm{L} 2}$ and SHP $\mathrm{L}^{\mathrm{L}-\mathrm{L}-}$ mice. $\left({ }^{*}\right) p<0.05$. (E) Quantitative RT-PCR analysis of $l h c g r, f_{s h}, l_{r h}-1, s h p, s f-1$, and $f_{x} \alpha$ in extracts of liver, adrenals, whole testis, and laser-microdissected interstitial or tubular compartments of testis of 12 -wk-old C57BL/6J mice $(n=3) .\left(^{\star}\right) p<0.05$. 
plasma LH, as levels were identical between $\mathrm{SHP}^{\mathrm{L} 2 / \mathrm{L} 2}$ and $\mathrm{SHP}^{\mathrm{L}-/ \mathrm{L}-}$ mice (Fig. 1D). To further examine eventual central effects via $\mathrm{LH}$, mice were stimulated with hCG. Both $\mathrm{SHP}^{\mathrm{L} 2 / \mathrm{L} 2}$ and $\mathrm{SHP}^{\mathrm{L}-/ \mathrm{L}-}$ mice responded to hCG treatment with an increase in plasma testosterone. However, no differences in gonadotropin responsiveness (Supplementary Fig. S1a) or in the induction of the steroidogenic genes star and cyp11a1 could be observed between both genotypes (Supplementary Fig. S1b). These results suggest that local, but not central, regulatory mechanisms are responsible for the increased testosterone production in $\mathrm{SHP}^{\mathrm{L}-/ \mathrm{L}-}$ mice.

\section{SHP is expressed in the interstitial cells} of the adult testis

As shp has been shown to be expressed at a very low level in the testes as compared with the liver (Johansson et al. 1999; Lu et al. 2001), it was intriguing to note that deletion of SHP led to such an increase in testicular testosterone synthesis. In agreement with these studies, only low levels of $s h p$ mRNA were measured in the testis, evoking the possibility that $s h p$ might be confined to a specific cell type in the adult testis (Fig. 1E). To test this hypothesis, we purified interstitial and tubular cells from the adult testes using laser microdissection (LMD). The mRNA expression pattern-characterized by low Fsh receptor $\left(f_{s h}\right)$ and high Lh receptor (Ihcgr) expression in the interstitial cells, and low lhcgr and high fshr expression in the tubular cells-demonstrated the cellular purity of our LMD samples (Fig. 1E). shp mRNA levels were significantly higher in the interstitial compartment, including steroidogenic Leydig cells, as compared with the tubular cells, including Sertoli cells (Fig. 1E). Similar results on $s h p, l h c g r$, and $f s h r$ expression were obtained using the MA10 Leydig cell line and the MscI Sertoli cell line (data not shown). Furthermore, in addition to SHP, the expression of the NRs $1 r h-1$ and $s f-1$ and farnesoid X receptor $\alpha\left(f_{X} \alpha \alpha\right.$; N $\left.1 \mathrm{H} 4\right)$ were all enriched in the interstitial cells of the adult testis, most likely in the Leydig cells (Fig. 1E).

\section{SHP regulates testicular steroidogenesis via $L R H-1$}

Steroidogenic genes have been shown to be regulated by both SF-1 and LRH-1 in vitro (Bakke et al. 2001; Kim et al. 2004, 2005; Mueller et al. 2006). In agreement with a previous report (Pezzi et al. 2004), we confirmed that the mRNA of $1 r h-1$ was clearly expressed in the interstitial cells (Fig. 1E). We then examined the role of LRH-1 in testicular steroidogenesis using heterozygous LRH-1-deficient $\left(\mathrm{LRH}-1^{+/-}\right)$and wild-type $\left(\mathrm{LRH}-1^{+/+}\right)$mice (Botrugno et al. 2004). LRH-1 $1^{+/-}$mice showed lower plasma testosterone concentrations compared with $\mathrm{LRH}-1^{+/+}$ mice (Fig. 2A). This effect appeared to be intratesticular, as plasma $\mathrm{LH}$ concentrations and pituitary $1 \mathrm{hb}$ mRNA in the $\mathrm{LRH}-1^{+/-}$mice were not lower than in their wildtype littermates (Fig. 2B). By contrast, the lower testosterone secretion could be explained by the lower mRNA levels of steroidogenic genes star, cyp11a1, and $3 \beta$-hsd in the testis of $\mathrm{LRH}_{-1} \mathrm{1}^{+-}$mice (Fig. 2C). Consistent with these data, the weights of the epidydimides and seminal vesicles were lower in LRH-1 ${ }^{+/}$(Fig. 2D).

Interestingly, both $1 r h-1$ and $s f-1$ were expressed at a higher level in $\mathrm{SHP}^{\mathrm{L}-/ \mathrm{L}-}$ relative to $\mathrm{SHP}^{\mathrm{L} 2 / \mathrm{L} 2}$ mice (Fig. 1B). The increased expression of $1 r h-1$ and $s f-1$ could hence contribute to the enhanced steroidogenesis of $\mathrm{SHP}^{\mathrm{L}-/ \mathrm{L}-}$ mice. The opposite effect on mRNA expression of steroidogenic genes and on plasma testosterone concentrations, and its ensuing effects on reproductive organs in $\mathrm{SHP}^{\mathrm{L}-/ \mathrm{L}-}$ and $\mathrm{LRH}-1^{+/-}$mice, suggested that, in addition to its effect on $1 r h-1$ and $s f-1$ expression, SHP could also inhibit steroidogenesis through a direct inhibitory interaction with LRH-1 (Lu et al. 2000; Li et al. 2005). The hypothesis of a functional interaction between SHP and LRH-1 in the control of the testicular steroidogenesis was validated in vitro, using transient transfection experiments of a luciferase reporter construct under the control of the promoter of the mouse star gene encoding the first enzyme in steroidogenesis. Transfection of COS-1 cells with the mLRH-1 expression vector alone induced star promoter activity, while cotransfection of SHP decreased the LRH-1-dependent transactivation of the star promoter in a dose-dependent manner (Fig. 2E).

The ability of SHP to interact with LRH-1 on the LRH-1 response elements (LRH-1-RE) in the promoters of two key steroidogenic genes-i.e., star and cyp11a1was then evaluated by chromatin immunoprecipitation (ChIP). TM3 Leydig cells were therefore transfected with a pCMV2-Flag-SHP with or without a pCMX-LRH-1 expression vector, as we could not immunoprecipitate endogenous SHP protein in vivo due to the lack of a good anti-SHP antibody. Using an anti-LRH-1 antibody, LRH-1 was detected on the sequences surrounding the LRH-1-RE, but not on genomic DNA located 4.0-2.4 kb upstream of the LRH-1-RE in both star and cyp11a1 genes (Fig. 2F). SHP, as detected by an anti-Flag antibody, was also only present at the LRH-1-RE, but not on the DNA upstream of the LRH-1-RE on both LRH-1 target genes (Fig. 2G). The interaction between LRH-1 and SHP on the star promoter was also supported by the fact that higher levels of SHP were immunoprecipated when cells were cotransfected with LRH-1 and SHP expression vectors (Fig. 2G).

Since SHP has also been shown to interact with LXR (Brendel et al. 2002), another NR involved in adrenal steroidogenesis (Cummins et al. 2006), we expected that the LXR signaling pathway might also be altered in the $\mathrm{SHP}^{\mathrm{L}-/ \mathrm{L}-}$ mice. Interestingly, neither the mRNA levels of the two LXR isoforms nor the expression of their target genes, such as srebp1c and abca1, were altered in the $\mathrm{SHP}^{\mathrm{L}-/ \mathrm{L}-}$ mice (data not shown), arguing against the involvement of LXR in the regulation of testicular steroidogenesis by SHP.

The expression of SHP is regulated by $F X R \alpha$ in the testis

In the liver, the expression of $s h p$ has been shown to be induced by $\operatorname{FXR} \alpha$, a transcriptional effect that underlies 
Volle et al.
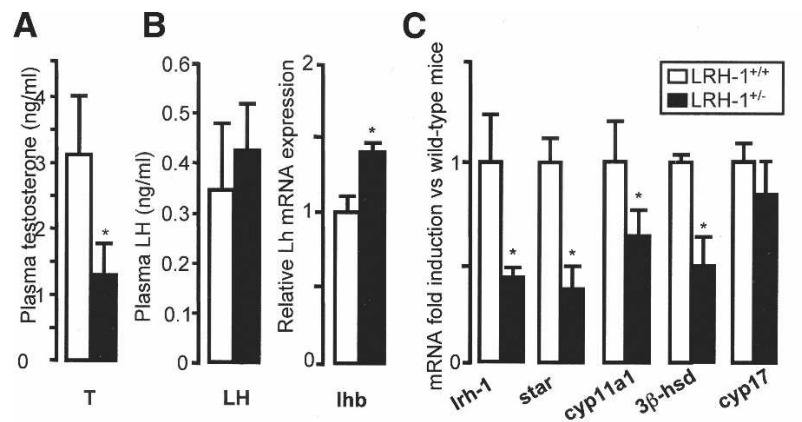

D

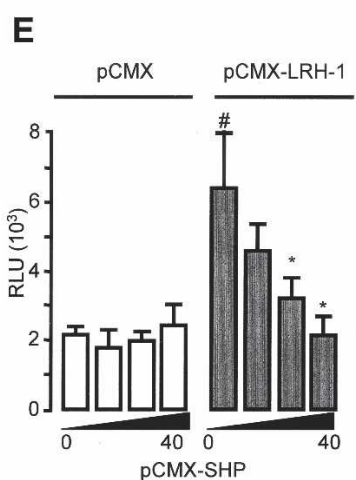

F

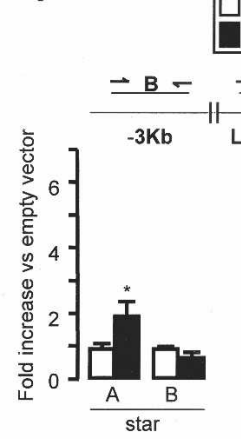

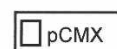
pCMX-LRH-1
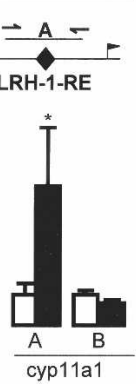

Body Weight $29.6 \pm 1.0 \quad 29.2 \pm 1.4$

Liver $\quad 5.34 \pm 0.11 \quad 4.95 \pm 0.65$

Spleen $\quad 0.32 \pm 0.04 \quad 0.41 \pm 0.08$

Epidydimis $\quad 0.30 \pm 0.03 \quad 0.25 \pm 0.01^{*}$

Seminals $\quad 1.06 \pm 0.05 \quad 0.76 \pm 0.04^{*}$

$\begin{array}{lll}\text { Testis } & 0.72 \pm 0.06 \quad 0.79 \pm 0.05\end{array}$

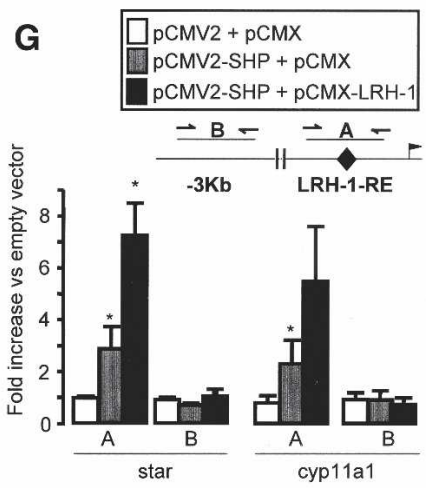

Figure 2. $\mathrm{LRH}-1^{+/-}$and SHP $\mathrm{L}^{\mathrm{L}-\mathrm{L}-}$ mice show opposite testicular phenotypes. (A) Plasma testosterone concentrations in LRH- $1^{+/+}$and LRH- $1^{+/-}$mice $\left(n=10-15\right.$ per group). $\left(^{*}\right) p<0.05$. (B) Plasma LH and pituitary mRNA expression of $1 h b$ in LRH- $1^{+/+}$and LRH- $1^{+/-}$mice.

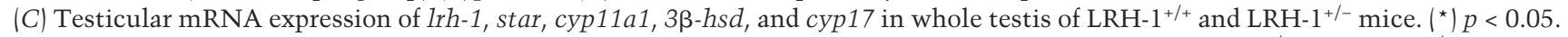
$(D)$ Weights of liver, spleen, testis, epididymides, and seminal vesicles normalized to body weight in LRH- $1^{+/+}$and $\mathrm{LRH}-1^{+/-}$mice. $\left({ }^{\star}\right)$ $p<0.05$. (E) Transient transfection assay of COS-1 cells cotransfected with a mouse star promoter luciferase reporter plasmid together with either empty pCMX or the pCMX-mLRH-1 expression plasmid. An increasing dose of the pCMX-mSHP expression plasmid was cotransfected (0-40 ng). Normalized luciferase activity was expressed as relative light units (RLU) of triplicate assays (mean \pm SD). $\left({ }^{\star}\right)$ $p<0.05$. (F) ChIP assay performed to detect LRH-1 on genomic sequences of the star and cyp11a1 genes in TM3 Leydig cells transfected either with pCMX or pCMX-LRH-1 using an anti-LRH-1 antibody. A sequence of \pm 100 bp covering either the LRH-1-RE (A) or a sequence 4.0-2.4 kb upstream of the LRH-1-RE (B) was amplified. Results are expressed as fold enrichment over cells transfected with pCMX and represent amplification variability $(n=4)$. $(G)$ ChIP to detect SHP on genomic DNA isolated from TM3 Leydig cells transfected either with pCMX and pCMV2, pCMX and pCMV2-Flag-SHP or pCMX-LRH-1 and pCMV2-Flag-SHP using an anti-Flag antibody. DNA amplification of the sequences of the star and cyp11a1 genes was performed as described in $F$.

the negative feedback regulation of bile acid homeostasis (Goodwin et al. 2000; Lu et al. 2000). As fxro was expressed in the interstitial cells (Fig. 1E), the possibility of an involvement of $\mathrm{FXR} \alpha$ in the regulation of testicular steroidogenesis was examined using the synthetic FXR $\alpha$ agonist GW4064. Consistent with the role of FXR $\alpha$ as a regulator of $s h p$ in the liver (Goodwin et al. 2000; Lu et al. 2000), administration of GW4064 also induced shp mRNA expression in the testis (Fig. 3A). The up-regulation of $s h p$ mRNA by GW4064 was strictly FXR $\alpha$ dependent, as GW4064 had no effect on shp mRNA levels in $\mathrm{FXR}^{-/-}$mice (Fig. 3A). Interestingly, no differences in the basal mRNA expression levels of shp and steroidogenic genes such as star, cyp11a1,3ßhsd-I, and cyp17 could be observed between FXR $\alpha^{+/+}$and FXR $\alpha^{-/-}$mice (data not shown). Consistent with this result, FXR $\alpha^{-/-}$ mice had normal levels of plasma testosterone (Fig. 3B).

In view of the absence of a direct effect of FXR $\alpha$ deficiency on steroidogenesis, we administrated an FXR agonist as a way to induce SHP expression. Therefore, 12wk-old SHP ${ }^{\mathrm{L} 2 / \mathrm{L} 2}$ mice were given GW4064 and sacrificed 6 and $12 \mathrm{~h}$ after administration of GW4064. GW4064 induced testicular mRNA expression of shp from $6 \mathrm{~h}$ onward, and subsequently decreased the mRNA levels of star, cyp11a1, and $3 \beta$-hsd, highlighting the repressive activity of SHP on steroidogenesis in the testis (Fig. 3C). Consistent with the role of SHP in steroidogenesis, the effects of GW4064 were lost in the $\mathrm{SHP}^{\mathrm{L}-/ \mathrm{L}-}$ mice. No change was observed in cyp17 mRNA following the administration of an FXR $\alpha$ agonist in $\mathrm{SHP}^{\mathrm{L} 2 / \mathrm{L} 2}$ mice (Fig. $3 \mathrm{C})$, in line with the unaltered cyp17 mRNA expression in $\mathrm{SHP}^{\mathrm{L}-/ \mathrm{L}-}$ mice (Fig. 1B). The FXR $\alpha$ agonist induced an acute decline in both plasma (Fig. 3D) and testicular (data not shown) testosterone concentrations $12 \mathrm{~h}$ posttreatment in $\mathrm{SHP}^{\mathrm{L} 2 / \mathrm{L} 2}$ mice, but not in $\mathrm{SHP}^{\mathrm{L}-/ \mathrm{L}-}$ mice. In combination, these data confirm that the impact of $\mathrm{FXR} \alpha$ activation on the testicular steroidogenesis is mediated via SHP.

\section{SHP-deficient mice have earlier sexual maturation}

As testosterone is an indisputable regulator of male fertility via its cognate $\mathrm{NR}$, the androgen receptor (AR: NR3C4) (De Gendt et al. 2004), we set out to determine 
A
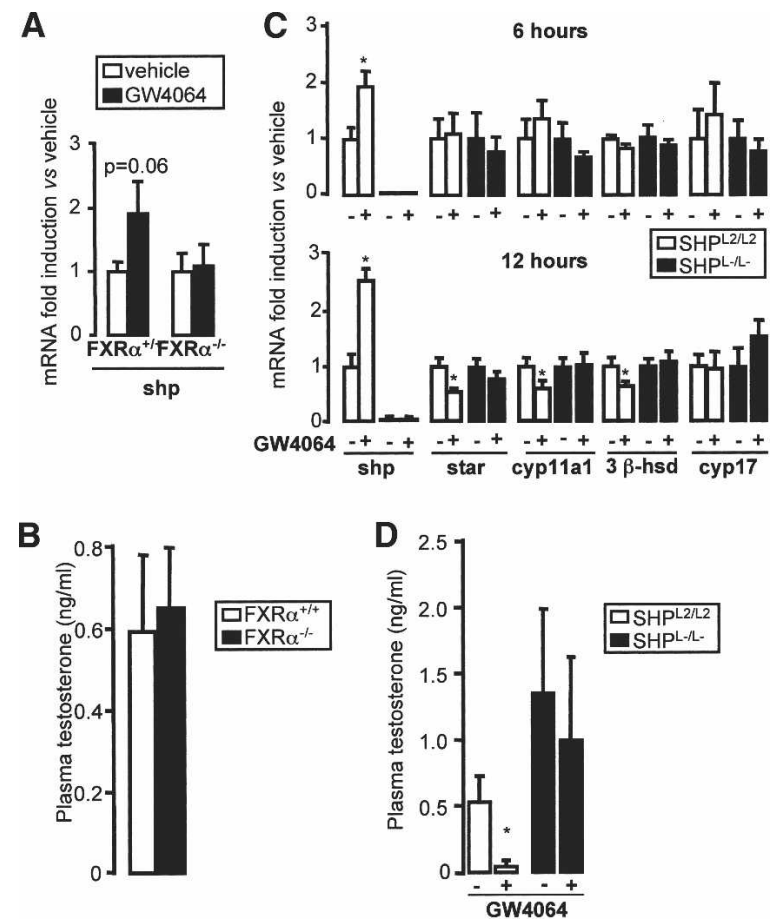

Figure 3. Role of FXR $\alpha$ in testicular testosterone production. (A) $\mathrm{FXR} \alpha^{+/+}$and $\mathrm{FXR} \alpha^{-/-}$mice ( $n=4-5$ per group) were injected with GW4064 (50 mg/kg, intraperitoneally) or vehicle (DMSO) for $6 \mathrm{~h}$. Testicular SHP mRNA expression was analyzed by quantitative RT-PCR. (B) Plasma testosterone levels in FXR $\alpha^{+/+}$ and $\mathrm{FXR} \alpha^{-1-}$ mice $(n=5)$. (C) Testicular mRNA expression of shp, star, cyp11a1, 3ß-hsd, and cyp17 in whole testis of SHP ${ }^{\mathrm{L} 2 /}$ L2 and SHP ${ }^{\mathrm{L}-/ \mathrm{L}-}$ mice injected with GW4064 $(50 \mathrm{mg} / \mathrm{kg}$, intraperitoneally) or vehicle (DMSO) for 6 or $12 \mathrm{~h}(n=6)$. All data are expressed as relative values with the nontreated samples assigned a value of $1 .\left(^{\star}\right) p<0.05$. (D) Plasma testosterone levels in $\mathrm{SHP}^{\mathrm{L} 2 / \mathrm{L} 2}$ and $\mathrm{SHP}^{\mathrm{L}-/ \mathrm{L}-}$ mice treated with GW4064 for $12 \mathrm{~h}$ $(n=6) .\left(^{\star}\right) p<0.05$.

the stage at which these male mice were able to reproduce, as an indicator of sexual maturation. Peripubertal $\mathrm{SHP}^{\mathrm{L} 2 / \mathrm{L} 2}$ or $\mathrm{SHP}^{\mathrm{L}-/ \mathrm{L}-}$ males (5 wk old) were housed together with sexually mature C57BL/6J females (8-10 wk old). $\mathrm{SHP}^{\mathrm{L}-/ \mathrm{L}-}$ males successfully impregnated the females $8 \mathrm{~d}$ earlier compared with SHP $\mathrm{L}^{\mathrm{L} 2 / \mathrm{L} 2}$ males $(44 \pm 2 \mathrm{~d}$ vs. $52 \pm 1 \mathrm{~d}$ of age, $n=5, p<0.001)$. There was no difference in the size of litters generated by $\mathrm{SHP}^{\mathrm{L} 2 / \mathrm{L} 2}$ or $\mathrm{SHP}^{\mathrm{L}-/ \mathrm{L}-}$ males (data not shown).

To understand this advancement in sexual maturation, we first analyzed the reproductive tract of SHP $\mathrm{L}^{\mathrm{L} / \mathrm{L} 2}$ and $\mathrm{SHP}^{\mathrm{L}-/ \mathrm{L}-}$ males. At $30 \mathrm{~d}$, the epidydimides and the seminal vesicles were already heavier in $\mathrm{SHP}^{\mathrm{L}-/ \mathrm{L}-}$ mice compared with $\mathrm{SHP}^{\mathrm{L} 2 / \mathrm{L} 2}$ mice (Fig. 4A). By contrast, testis weight was lower in $\mathrm{SHP}^{\mathrm{L}-/ \mathrm{L}-}$ males (Fig. 4A). We then analyzed the developmental expression pattern of shp in the interstitial cells in testes of C57BL/6J mice. A significant increase in the mRNA expression of $s h p$ was observed between 23 and $30 \mathrm{~d}$ (Fig. 4B), suggesting that shp increases during the process of Leydig cell maturation, which leads to puberty. The attainment of puberty in these mice was evidenced by a dramatic increase in the expression of Ihcgr in the interstitial cells. The increase in $s h p$ expression coincided with the period when the differences in the weight of reproductive organs between $\mathrm{SHP}^{\mathrm{L} 2 / \mathrm{L} 2}$ and $\mathrm{SHP}^{\mathrm{L}-/ \mathrm{L}-}$ mice became evident (Fig. 4A). Interestingly, Irh-1 expression paralleled that of lhcgr and $s h p$, whereas $s f-1$ mRNA expression did not change as dramatically during the period leading to puberty (Fig. 4B).

To further confirm the hypothesis that SHP is involved in male sexual maturation via its effect on testosterone synthesis, we analyzed plasma testosterone concentrations in $\mathrm{SHP}^{\mathrm{L} 2 / \mathrm{L} 2}$ and $\mathrm{SHP}^{\mathrm{L}-/ \mathrm{L}-}$ males during the peripubertal period. Concentrations began to increase sooner during the prepubertal development in $\mathrm{SHP}^{\mathrm{L}-/ \mathrm{L}-}$ compared with $\mathrm{SHP}^{\mathrm{L} 2 / \mathrm{L} 2}$ males $(28 \mathrm{~d}$ vs. $35 \mathrm{~d}$, respectively) (Fig. 4C). This earlier capacity of $\mathrm{SHP}^{\mathrm{L}-/ \mathrm{L}-}$ males to produce testosterone could be attributed to the precocious rise in testicular mRNA expression of 1 hcgr, star, and cyp11a1, which increased between 28 and $30 \mathrm{~d}$ postnatal in $\mathrm{SHP}^{\mathrm{L}-/ \mathrm{L}-}$ males, as opposed to $35-44 \mathrm{~d}$ postnatal in $\mathrm{SHP}^{\mathrm{L} 2 / \mathrm{L} 2}$ males (Fig. 4D). In line with this earlier induction of steroidogenic genes, at the age of $30 \mathrm{~d}$, the testicular mRNA expression of both $1 r h-1$ and $s f-1$ was also higher in $\mathrm{SHP}^{\mathrm{L}-/ \mathrm{L}-}$ males as compared with $\mathrm{SHP}^{\mathrm{L} 2 / \mathrm{L} 2}$ males (Supplementary Fig. S1c).

Intratesticular effects of androgens can sometimes be observed before their increase in plasma levels can be measured (Denolet et al. 2006). To exclude this possibility, we analyzed the expression of two AR target genes, pem and claudin-11, in the testis before $30 \mathrm{~d}$ of age. No differences in pem and claudin-11 mRNA expression could be observed at either 20 or $28 \mathrm{~d}$ of age, but their expression became higher in $\mathrm{SHP}^{\mathrm{L}-/ \mathrm{L}-}$ males relative to $\mathrm{SHP}^{\mathrm{L} 2 / \mathrm{L} 2}$ at $30 \mathrm{~d}$, when their plasma testosterone concentrations were already different (Supplementary Fig. S1d). These results indicated that before the age of $30 \mathrm{~d}$, the intratesticular testosterone concentrations were not different between the genotypes, or that the differences were not enough to cause differential expression of AR target genes. The absence of SHP might lead to an increase in testosterone synthesis from $28 \mathrm{~d}$ of age onward in $\mathrm{SHP}^{\mathrm{L}-/ \mathrm{L}-}$ males, as this timing is consistent with the beginning of the increase of SHP expression in the interstitial compartment of the normal testis (Fig. 4B).

\section{Earlier germ cell differentiation in $S H P^{L-/ L-}$ male mice}

To further validate the role of SHP in sexual maturation, we analyzed the age at which differentiated germ cells were detectable in the seminiferous tubes. At the age of $25 \mathrm{~d}$, almost none of the seminiferous tubules had elongated spermatids in the testes of both genotypes. However, at $28 \mathrm{~d}$ a significantly higher number of seminiferous tubules contained elongated spermatids in $\mathrm{SHP}^{\mathrm{L}-/ \mathrm{L}-}$ mice compared with $\mathrm{SHP}^{\mathrm{L} 2 / \mathrm{L} 2}$ mice $(13 \%$ vs. $1 \%$, respectively) (Fig. 4E,F). Consistent with their earlier reproductive capacity, $\mathrm{SHP}^{\mathrm{L}-/ \mathrm{L}-}$ mice had $100 \%$ of tubules with elongated spermatids at the age of $44 \mathrm{~d}$, whereas $\mathrm{SHP}^{\mathrm{L} 2 / \mathrm{L} 2}$ males caught up with the $\mathrm{SHP}^{\mathrm{L}-/ \mathrm{L}-}$ mice by $56 \mathrm{~d}$ of age (Fig. 4F). 

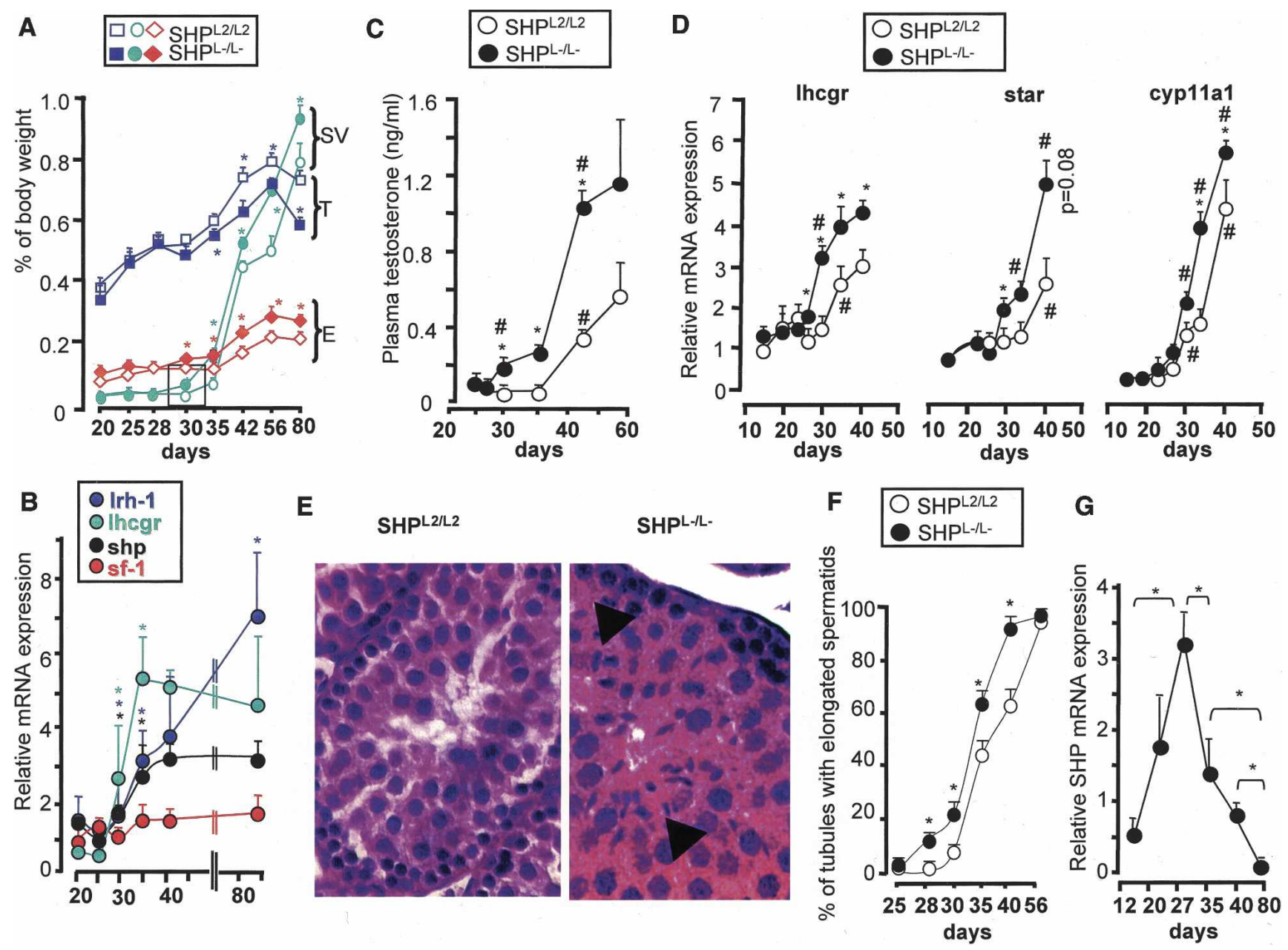

Figure 4. Early fertility and reproductive tract maturation in male SHP $\mathrm{L}^{\mathrm{L}-\mathrm{L}-}$ mice. $(A)$ Weights of testis $(\mathrm{T})$, epididymides $(\mathrm{E})$, and seminal vesicles $(\mathrm{SV})$ normalized for body weight in SHP $\mathrm{S}^{\mathrm{L} / \mathrm{L} 2}$ and $\mathrm{SHP} \mathrm{L}^{\mathrm{L}-/ \mathrm{L}-}$ mice $(n=6) .\left(^{\star}\right) p<0.05$. $(B)$ Expression of $s h p, 1 h c g r, s f-1$, and $1 r h-1$ mRNA in the interstitial testicular compartment in samples obtained at different stages of the postnatal development by $\mathrm{LMD}(n=3)$. Asterisk denotes difference from previous time point $(p<0.05)$. (C) Plasma testosterone concentrations from C57BL/6J mice between 25 and $56 \mathrm{~d}(n=6)$. (D) Testicular mRNA expression of 1 cgr, star, and cyp11a1 in whole testis of SHP ${ }^{\mathrm{L} 2 / \mathrm{L} 2}$ and SHP $\mathrm{L}^{\mathrm{L}-\mathrm{L}-}$ mice during postnatal development $(n=6)$. Asterisk denotes significant difference between genotypes $(p<0.05)$, and number sign $(\#)$ denotes difference in the same genotype with the previous time point. $(E)$ Two representative micrographs of eosin-hematoxylinstained testis of 28 -d-old SHP ${ }^{\mathrm{L} 2 / \mathrm{L} 2}$ and SHP ${ }^{\mathrm{L}-/ \mathrm{L}-}$. Arrows indicate elongated spermatids. $(F)$ Testes from 20- to 56-d-old SHP ${ }^{\mathrm{L} 2 / \mathrm{L} 2}$ and $\mathrm{SHP}^{\mathrm{L}-/ \mathrm{L}-}$ mice were collected, processed for histology, and stained with eosin-hematoxylin. For each testis, the number of seminiferous tubules showing elongated spermatids were counted, and the results are expressed as the number of positive tubules per 100 tubules $(n=6) .\left(^{*}\right) p<0.05$. (G) Mean mRNA expression of shp in seminiferous tubular cells of the testes of C57BL/6J mice of different ages, purified by LMD. $\left(^{*}\right) p<0.05$.

Intriguingly, the differential appearance of elongated spermatids in the seminiferous tubules began between 25 and $28 \mathrm{~d}$ in $\mathrm{SHP}^{\mathrm{L}-/ \mathrm{L}-}$ mice (Fig. 4F), the period when the plasma testosterone concentrations (Fig. 4C) and the testosterone target genes in the testes were still unchanged between SHP $\mathrm{L}^{\mathrm{L} / \mathrm{L} 2}$ and $\mathrm{SHP}^{\mathrm{L}-/ \mathrm{L}-}$ males (Supplementary Fig. S1d). Thus the earlier appearance of elongated spermatids in SHP ${ }^{\mathrm{L}-/ \mathrm{L}-}$ mice could not be attributed to the higher plasma testosterone levels alone. This led us to presume that $\operatorname{sh} p$ might be locally expressed in the tubular cells during postnatal development and that lack of its expression could lead to the precocious germ cell maturation in $\mathrm{SHP}^{\mathrm{L}-/ \mathrm{L}-}$ mice. Consistent with this hypothesis, shp mRNA levels increased between 10 and $25 \mathrm{~d}$ in the tubular cells of the testis and then declined to a nadir by the age of $80 \mathrm{~d}$ (Fig. 4G). This developmental expression pattern of SHP suggested that in addition to its role in the regulation of steroidogenesis, SHP could also be implicated in germ cell differentiation.

\section{SHP knockout mice have earlier meiotic entry of germ cells}

Germ cell differentiation is controlled by apoptosis, proliferation, and differentiation (Wolgemuth et al. 2002). Using TUNEL assay and Ki-67 immunostaining, we ex- 
cluded differences in apoptosis and proliferation rates in testis of $\mathrm{SHP}^{\mathrm{L} 2 / \mathrm{L} 2}$ and $\mathrm{SHP}^{\mathrm{L}-/ \mathrm{L}-}$ males at 25 and $28 \mathrm{~d}$ (Supplementary Fig. S1e,f). We then analyzed the expression of the cyclins specific to mitosis or meiosis (Fig. 5A). Between 11 and $20 \mathrm{~d}$-well before the precocious rise in the plasma testosterone concentrations-the mRNA expression of the mitotic cyclins, cyclin a2 and cyclin d2, was lower in $\mathrm{SHP}^{\mathrm{L}-/ \mathrm{L}-}$ compared with $\mathrm{SHP}^{\mathrm{L} 2 / \mathrm{L} 2}$ males. In contrast, in the same age period, mRNA expression of the meiotic cyclin $a 1$ and cyclin b2 was higher in $\mathrm{SHP}^{\mathrm{L}-/ \mathrm{L}-}$ males, suggesting earlier meiotic differentiation of germ cells. This presumption was confirmed by the higher expression of two genes expressed during germ cell maturation-the germ cell nuclear factor $(g c n f)$, and the steroidogenic acute regulatory proteinrelated lipid transfer domain 6 (stard6)-in $\mathrm{SHP}^{\mathrm{L}-/ \mathrm{L}-}$ males of $20 \mathrm{~d}$ old (Fig. 5A).

\section{SHP regulates germ cell differentiation in the testis via the RA pathway}

Male germ cell transition from mitosis to meiosis is poorly understood. Since RA and the RA receptors $\operatorname{RAR} \alpha, \operatorname{RAR} \beta$, and RAR $\gamma$ have been shown to be involved in the germ cell transition to meiosis /Chung and Wolgemuth 2004), we analyzed the expression of the genes involved in the RA pathway in the testis of $\mathrm{SHP}^{\mathrm{L}-/ \mathrm{L}-}$ and $\mathrm{SHP}^{\mathrm{L} 2 / \mathrm{L} 2}$ males. The RA target gene, stimulated by RA gene 8 (stra8), has recently been shown to be critical for meiotic initiation and progression of germ cells (Baltus et al. 2006; Bowles et al. 2006; Koubova et al. 2006). Even though mRNA levels of rara, rar $\beta$, and rary did not differ between the two genotypes, expression of stra8 was higher in the $\mathrm{SHP}^{\mathrm{L}-/ \mathrm{L}-}$ mice at the age of $8-15 \mathrm{~d}$ (Fig. 5B). Interestingly, this earlier increase in stra8 expression preceded the increase in the expression of the meiotic cyclin $a 1$ and cyclin b2 (Fig. $5 \mathrm{~A})$ and the subsequent appearance of elongated spermatids in the tubules of SHP ${ }^{\mathrm{L}-/ \mathrm{L}-}$ testes (Fig. 4F). The expression of several other known RAR target genes-such as disrupted meiotic gene $1(d m c 1)$, synaptonemal complex protein 3 (scp3), caudal homeobox gene (cdx1), and homeobox-a1 (hoxa1) — was also higher in $\mathrm{SHP}^{\mathrm{L}-/ \mathrm{L}-}$ mice (Fig. 5B).

The earlier increase in the expression of RA target genes, despite unaltered expression of RARs, indicated that $\mathrm{SHP}^{\mathrm{L}-/ \mathrm{L}-}$ testis could be submitted to enhanced $\mathrm{RA}$ signaling. This hypothesis was supported by the decreased testicular expression of cyp26b1, an enzyme that degrades RAs (Bowles et al. 2006) in the testis of $\mathrm{SHP}^{\mathrm{L}-/ \mathrm{L}-}$ mice (Fig. 5B). Moreover, at the age of $9 \mathrm{~d}$ the intratesticular concentrations of all-trans RA were higher in a pool of testis collected from $20 \mathrm{SHP}^{\mathrm{L}-/ \mathrm{L}-}$ mice compared with a pool of testis collected from 20 $\mathrm{SHP}^{\mathrm{L} 2 / \mathrm{L} 2}$ mice (Fig. 6A). No difference, however, was observed in the testicular concentrations of all-trans retinol and all-trans retinylesters (Fig. 6A). Interestingly, there was no difference in liver all-trans RA concentration between $\mathrm{SHP}^{\mathrm{L}-/ \mathrm{L}-}$ and $\mathrm{SHP}^{\mathrm{L} 2 / \mathrm{L} 2}$ mice (data not shown). Thus this increased availability of RA in testes
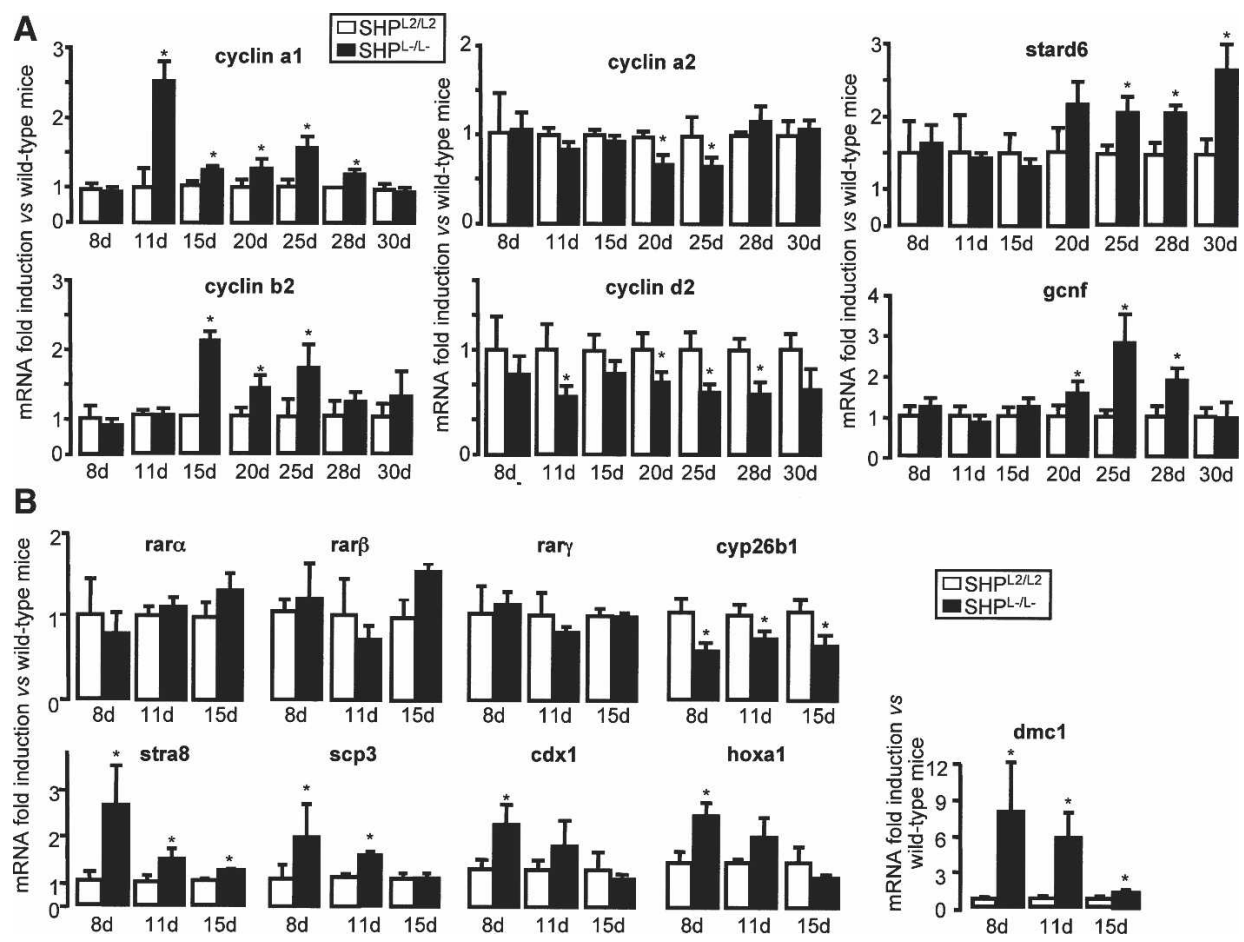

Figure 5. Earlier germ cell differentiation in male SHP $\mathrm{L}^{\mathrm{L}-\mathrm{L}-}$ mice. $(A)$ Testicular mRNA expression of $c y c l i n a 1, c y c l i n b 2, c y c l i n a 2$, cyclin d2, stard6, and gcnf in whole testis of 8-, 11-, 15-, 20-, 25-, 28-, and 30-d-old SHP ${ }^{\mathrm{L} 2 / \mathrm{L} 2}$ and SHP ${ }^{\mathrm{L}-/ \mathrm{L}-}$ mice $(n=6) .\left({ }^{\star}\right) p<0.05 .(B)$

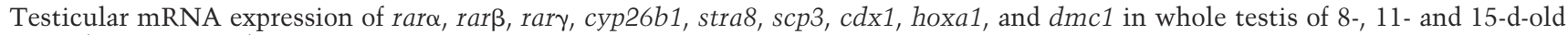
$\mathrm{SHP}^{\mathrm{L} 2 / \mathrm{L} 2}$ and $\mathrm{SHP}^{\mathrm{L}-/ \mathrm{L}-}$ mice $(n=6) .\left(^{\star}\right) p<0.05$. 
Volle et al.

A

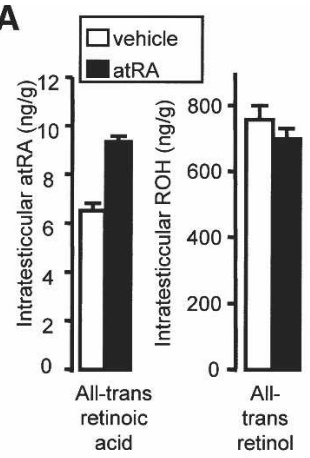

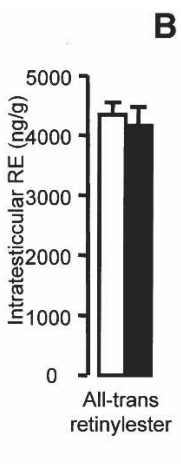

B
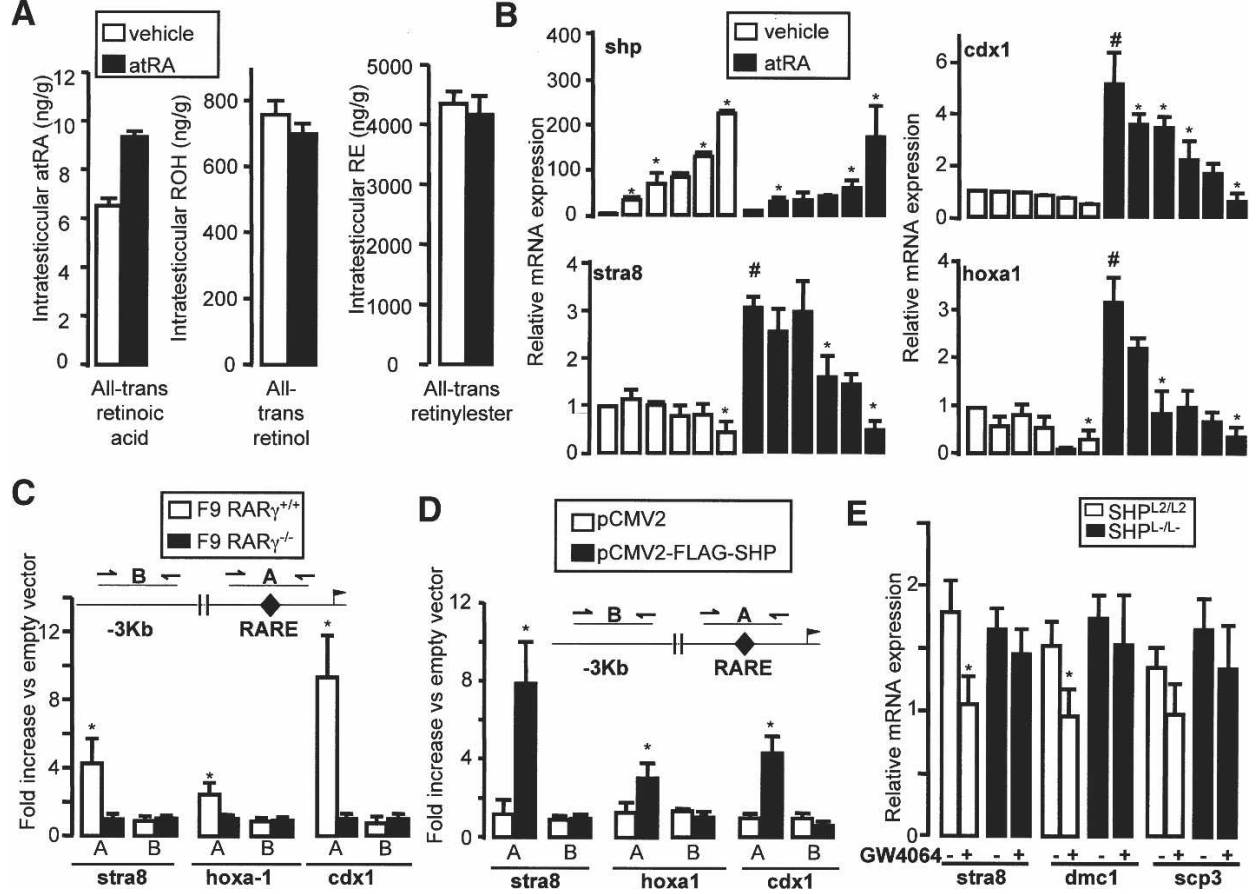

Figure 6. Lack of SHP in the tubular testis compartment alters expression of genes involved in RA signaling. (A) Intratesticular concentrations of all-trans RA, all-trans retinol, and all-trans retinylester in 9-d-old SHP ${ }^{\mathrm{L} 2 / \mathrm{L} 2}$ and SHP ${ }^{\mathrm{L}-/ \mathrm{L}-}$ mice. Each sample represents a pool of the testis of 20 mice. (B) mRNA expression of $s h p$, stra8, hoxa1, and $c d x 1$ in F9 cells transfected with increasing amounts of pCMX-SHP $(0-1 \mu \mathrm{g})(n=3)$. Asterisk denotes difference from the previous amount of transfected pCMX-SHP $(p<0.05)$, and number sign (\#) denotes difference between vehicle and atRA-treated cells. (C) ChIP of cross-linked DNA for RAR $\gamma$ from F9-RAR $\gamma^{+/+}$ and F9-RAR $\gamma^{-/-}$using an anti-RAR $\gamma$ antibody. A sequence of $\pm 100 \mathrm{bp}$ covering either the RARE (A) or a sequence $4.0-2.4 \mathrm{~kb}$ upstream of the RARE (B) was amplified. Results are expressed as fold enrichment over F9-RAR $\gamma^{-/-}$cells and represent amplification variability $(n=4)$. $(D)$ ChIP from F9-RAR $\gamma^{+/+}$transfected with either pCMV2 or pCMV2-Flag-SHP using an anti-Flag antibody. DNA amplification and expression of results were as in $C .\left(^{\star}\right) p<0.05$. (E) mRNA expression of stra8, dmc1, and scp3 in whole testis of SHP ${ }^{\mathrm{L} 2 / \mathrm{L} 2}$ and $\mathrm{SHP}^{\mathrm{L}-/ \mathrm{L}-}$ mice injected with GW4064 (50 mg/kg, intraperitoneally) or vehicle (DMSO) for $12 \mathrm{~h}(n=6) .\left(^{\star}\right) p<0.05$.

of the SHP $\mathrm{L}^{\mathrm{L}-\mathrm{L}-}$ mice could underpin the enhanced expression of RAR target genes, including stra8, thereby advancing the meiotic differentiation of the germ cells.

Another hypothesis that could explain the enhanced RA signaling is an eventual repressive action of SHP on RAR-mediated gene activation (Seol et al. 1996). In order to verify whether such a direct effect of SHP may exist on RAR activity, F9 cells were transfected with an increasing amount of mSHP expression vector in the presence or absence of RA. SHP repressed the RA-induced mRNA expression of stra8, $c d x 1$, and hoxa1 in a dosedependent manner (Fig. 6B). SHP hence seems to suppress RAR target genes through an inhibition of RAR activity. Such a potential interaction of SHP with RAR on the promoters of RAR target genes was further examined by ChIP experiments. First, ChIP was performed in wild-type or RAR $\gamma$ knockout $\left(\mathrm{RAR}^{-/-}\right)$F9 cells using an anti-RAR $\gamma$ antibody. In wild-type cells, but not in the RAR $\gamma^{-/-}$cells, RAR $\gamma$ was present on the RAR response element (RARE) of the stra8, hoxa1, and $c d x-1$ genes; no RAR $\gamma$ was present on a genomic DNA sequence $\pm 2.4 \mathrm{~kb}$ upstream of the RAREs in these three RAR target genes (Fig. 6C). ChIP was then performed using F9 cells that were transfected with either pCMV2 or pCMV2-FlagSHP vectors (Fig. 6D). Using an anti-Flag antibody, SHP was specifically enriched only on the DNA sequences surrounding the RAREs of the stra8, hoxa1, and $c d x 1$ promoters (Fig. 6D). The regulation of RAR target genes by SHP was further supported by the fact that the mRNA levels of stra8, dmc1, and scp3 were lower in SHP $\mathrm{S}^{\mathrm{L} / \mathrm{L} 2}$ mice treated with the FXR agonist GW4064, which induces SHP expression (Fig. 6E). This effect was lost in $\mathrm{SHP}^{\mathrm{L}-/ \mathrm{L}-}$ males (Fig. 6E). In combination, these data strongly suggest a repressive role of SHP on germ cell differentiation that is linked to the inhibition of RA signaling in the absence of which the mitotic germ cells precociously embark on the meiotic pathway.

\section{Discussion}

The testis is a heterogeneous organ composed of different cell types like germinal cells, Leydig cells, Sertoli cells, and peritubular cells. Studies on the whole testis are often confounded by this cellular complexity. So far, the reported data on $s h p$ expression in the testis relied on PCR or Northern blot analyses performed on samples from whole testis, leading to the conclusion that $s h p$ is expressed at very low levels in the testis (Johansson et al. 1999; Lu et al. 2001). The use of purified cells, obtained by LMD, allowed us to determine that the NRs lrh-1, 
$f_{x r} \alpha$, and $s h p$ are highly expressed in the interstitial cells of the adult testis. Furthermore, we also show that shp is transiently expressed in the tubular cells of the seminiferous tubules of the testis during early postnatal development and that its expression declines as the mouse attains sexual maturity.

SHP is mainly known for its function in the regulation of bile acid homeostasis, a role that was unequivocally established by the characterization of two independently derived SHP-deficient mouse models (Kerr et al. 2002; Wang et al. 2002; L. Wang et al. 2003). Here, we demonstrate that genetic deletion of $s h p$ results in a higher testosterone production due to enhanced expression of steroidogenic genes like star and cyp11a1. We have shown that two nonmutually exclusive mechanisms explain how SHP represses testicular steroidogenesis. One works by inducing the mRNA expression of $s f-1$ and Irh-1, and the other by directly inhibiting the transcriptional activity of LRH-1. The fact that $\mathrm{SHP}^{\mathrm{L}-/ \mathrm{L}-}$ males produce higher levels of testosterone, despite smaller testes, is intriguing. Nonetheless, there have been reports wherein deletion of Fshb or Fshr resulted in decreased testicular size without affecting puberty and fertility, demonstrating that the size of the testes does not necessarily translate into male fertility (Dierich et al. 1998; Abel et al. 2000).

LRH-1 and SF-1 recognize the same DNA-binding sites and have been shown to control the expression of many steroidogenic genes (Bakke et al. 2001; Kim et al. 2004, 2005; Mueller et al. 2006). As SHP was known to repress LRH-1, and both NRs are coexpressed in interstitial cells, we hypothesized that LRH-1 might regulate testicular steroidogenesis. In support of this hypothesis, we found that LRH-1 ${ }^{+/}$mice expressed lower levels of star and cyp11a1 mRNA in testes, leading to significantly lower circulating testosterone levels. This also explains the lower weights of epidydimides and seminal vesicles in the $\mathrm{LRH}-1^{+/-}$mice. As the expression of $s h p$ increases significantly in the interstitial testicular compartment at the time of puberty (25-30 d of age), it is reasonable to assume that SHP represses testosterone production in part by inhibiting LRH-1 activity. However, the expression of the steroidogenic genes, such as star, is controlled by multiple pathways (Manna et al. 2003), so it is too simplistic to assume that the effects of SHP on steroidogenesis are all mediated by its interaction with LRH-1. This idea of complexity is also enlightened by the derepression of the $s f-1$ expression in $\mathrm{SHP}^{\mathrm{L}-/ \mathrm{L}-}$ mice.

The atypical NRs, Dax-1 and SHP, are structurally similar in that they both lack a DNA-binding domain. Furthermore, Dax-1 and SHP repress the transcriptional activity of other receptors, with Dax-1 repressing SF-1 (Crawford et al. 1998) and SHP inhibiting LRH-1 (Lu et al. 2000). The study of a Leydig cell-specific Dax-1-deficient model suggested that Dax-1 controls only the expression of cyp19, the enzyme driving the aromatization of androgens to estrogens (Wang et al. 2001). No effect of Dax-1 on testicular testosterone production was demonstrated in this study (Wang et al. 2001). The current re- sults, however, show that testicular testosterone production might be subject to control by SHP, which regulates the expression of several steroidogenic genes. This role for both SHP and LRH-1 in androgen biosynthesis seems, furthermore, to not be compensated by the SF-1/Dax1 signaling pathway.

Like LRH-1 and SHP, FXR $\alpha$ is also known for its role in the transcriptional control of genes involved in the enterohepatic recycling and detoxification of bile acids (Russell 1999; Houten et al. 2006) as well as genes involved in metabolic homeostasis (Francis et al. 2003). Here we show that $\mathrm{FXR} \alpha$ controls the testosterone production in the interstitial compartment of the adult testis through the induction of SHP expression. Through the characterization of animals that are genetically deficient in SHP, LRH-1, or FXR $\alpha$ combined with a pharmacological approach using $\mathrm{FXR} \alpha$ agonists, we elucidated here a role for SHP, LRH-1, and FXR $\alpha$ in the regulation of testicular testosterone biosynthesis that is analogous to their function in bile acid homeostasis. The natural ligand that controls FXR $\alpha$ activity in the testis, and hence initiates the feedback inhibition of steroidogenesis, remains to be identified. $\operatorname{FXR} \alpha$ has been shown to be activated by conjugated and unconjugated bile acids, but it needs further study to define whether circulating levels of endogenous bile acids are able to affect testicular shp expression under physiological conditions. However, it is of interest to note that some androgen catabolites like androstedione have been shown to be potential $\mathrm{FXR} \alpha$ ligands (Howard et al. 2000; Wang et al. 2006) that could control a testicular feedback loop to repress androgen production.

In addition to its role in androgen synthesis, this study revealed another function of SHP during postnatal testicular development. SHP ${ }^{\mathrm{L}-/ \mathrm{L}-}$ mice showed an earlier differentiation of germ cells compared with control littermates, as suggested by the number of tubules showing elongated spermatids. Germ cell production by the testis is complex and involves different processes like cell proliferation, apoptosis, and differentiation (Weinbauer et al. 2001). In $\mathrm{SHP}^{\mathrm{L}-/ \mathrm{L}-}$ mice, the earlier germ cell differentiation did not involve alterations in apoptosis or cell proliferation. It seems, however, that $\mathrm{SHP}^{\mathrm{L}-/ \mathrm{L}-}$ germ cells transit earlier from a mitotic to a meiotic state, underpinning the earlier germ cell differentiation in $\mathrm{SHP}^{\mathrm{L}-/ \mathrm{L}-}$ males. This hypothesis is supported by the decreased expression of mitotic cyclin a 2 and cyclin $d 2$, the induction of meiotic cyclin $a 1$ and cyclin b2, and the higher expression of genes typical of germ cell maturation, such as gcnf and stard6.

So far, the molecular mechanisms triggering the initiation of germ cell differentiation, and in particular the mitotic/meiotic transition, are not completely understood. Our results indicate that the RA metabolic pathway is affected by the absence of SHP as shown by the altered expression of several RAR target genes. Among them, stra8, which has recently been demonstrated to be critical for meiotic initiation (Baltus et al. 2006; Bowles et al. 2006; Koubova et al. 2006), was induced in the $\mathrm{SHP}^{\mathrm{L}-/ \mathrm{L}-}$ mice. This increased expression of stra8 could 
be driven by the increased levels of RA in the testis of the $\mathrm{SHP}^{\mathrm{L}-/ \mathrm{L}-}$ mice. This presumption is supported by the recent demonstration of increased stra8 expression and the initiation of germ cell meiosis in response to RA administration to immature mice (Koubova et al. 2006). In the $\mathrm{SHP}^{\mathrm{L}-/ \mathrm{L}-}$ mice, there is a sequential increase in stra 8 mRNA ( $8 \mathrm{~d})$, followed by the modification of cyclin mRNA expression (11-20 d) and by the induction of genes expressed during the germ cell maturation $(20 \mathrm{~d})$. This sequence of events supports the hypothesis that SHP is involved in the control of germ cell differentiation through the regulation of the expression of the retinoic target gene, stra8.

The improved RA signaling in the SHP ${ }^{\mathrm{L}-/ \mathrm{L}-}$ mice is in part driven by a higher local concentration of all-trans RA in the testis of 9-d-old mice. The reduced expression of cyp26b1, which degrades RA, can surely contribute to the higher local levels of RA in the testis of $\mathrm{SHP}^{\mathrm{L}-/ \mathrm{L}-}$ mice. The mechanism by which cyp26b1 is down-regulated in the $\mathrm{SHP}^{\mathrm{L}-/ \mathrm{L}-}$ mice, however, remains unclear at this stage. Furthermore, SHP directly represses the expression of several RAR target genes like stra8, hoxa1, and $c d x-1$. This is in part explained by the fact that SHP is known to directly repress the transcriptional activity of the RARs (Seol et al. 1996). Consistent with this study, we detected both RAR $\gamma$ and SHP on the RAREs of the stra8, hoxa1, and $c d \times 1$ promoters in F9 cells. Furthermore, the reduction of RAR target genes in the testis of animals treated with a synthetic FXR agonist, resulting in the induction of SHP, is also in line with a direct repressive effect of SHP on RAR activity.

In conclusion, our data support a novel function of the NR SHP in the control of testicular androgen synthesis. On the one hand, SHP suppresses the mRNA expression of $s f-1$ and $l r h-1$. On the other hand, SHP acts through directly repressing the transcriptional activation of the steroidogenic genes by LRH-1. In addition, our data suggest that SHP is also involved in the control of germ cell differentiation. SHP reduces the local intratesticular RA levels and directly represses the activity of the RARs, hence reducing the expression of the critical RAR target gene stra8, which is key for the transition of mitotic germ cells into meiosis. Based on these findings, SHP turns out to be a gatekeeper at the testicular level to regulate the timing of sexual maturation (Fig. 7).

\section{Materials and methods}

\begin{abstract}
Animals
$\mathrm{SHP}^{\mathrm{L} 2 / \mathrm{L} 2}$ mice were generated according to the general conditional gene targeting strategy (Argmann et al. 2005) as part of a systematic effort at the Mouse Clinical Institute to generate alleles flanked by LoxP sites ("floxed" alleles) for all of the 49 NRs in the mouse (Supplementary Fig. S2; details available upon request). Briefly, following electroporation and selection, targeted 129sv ES cell clones were injected in C57BL/6J blastocysts that were implanted in foster mothers. Chimeric mice were then bred with C57BL/6J mice that express the Flp-recombinase under the control of the CMV promoter to excise the neomycin selection marker that was flanked by Frt sites. This breeding yielded offspring in which the SHP allele was flanked by two LoxP sites. Breeding these "floxed" SHP mice (SHP $2 / \mathrm{L} 2$ or wild-type mice) with mice that express the Cre-recombinase under the control of the CMV promoter generated SHP-deficient mice (SHP ${ }^{\mathrm{L}-\mathrm{L}-}$ or SHP knockout mice). Primers used for genotyping are available upon request. The generation of both LRH$1^{+/-}$mice (Botrugno et al. 2004) and FXR $\alpha^{-/-}$mice (Sinal et al. 2000) was described. SHP mice used in this study were maintained on a mixed background (C57BL/6J/129sv), whereas the LRH-1 $1^{+/-}$and $\mathrm{FXR} \alpha^{-/-}$mice were on C57BL/6J and 129 sv background, respectively. All mice were housed in temperature-controlled rooms with 12-h light/dark cycles. Mice had ad libitum access to food and water. Mice were injected intraperitoneally
\end{abstract}

Figure 7. Proposed model for the role of SHP in the onset of fertility. Our results indicate that SHP regulates the timing of fertility in the male via its repressive actions on testicular testosterone biosynthesis and on the entry of germ cells into meiosis. As $s h p$ expression in the seminiferous tubules increases during the late prepubertal period, its absence leads to the increased expression of meiosis-inducing genes like stra8. This effect is in part explained by the higher testicular RA levels and in part by the lack of the repressive activity of SHP on RARs. The increase in testicular RA could be explained by the decreased expression of the RA-degrading enzyme cyp26b1. SHP expression also increases in the interstitial cells during the prepubertal period, with its absence leading to a precocious increase in testosterone biosynthesis. SHP inhibits testicular steroidogenesis on the one hand by inhibiting the expression of $s f-1$ and $1 r h-1$ that control the expression of the steroidogenic genes, and on the other hand by repressing the transcriptional activity of LRH-1.
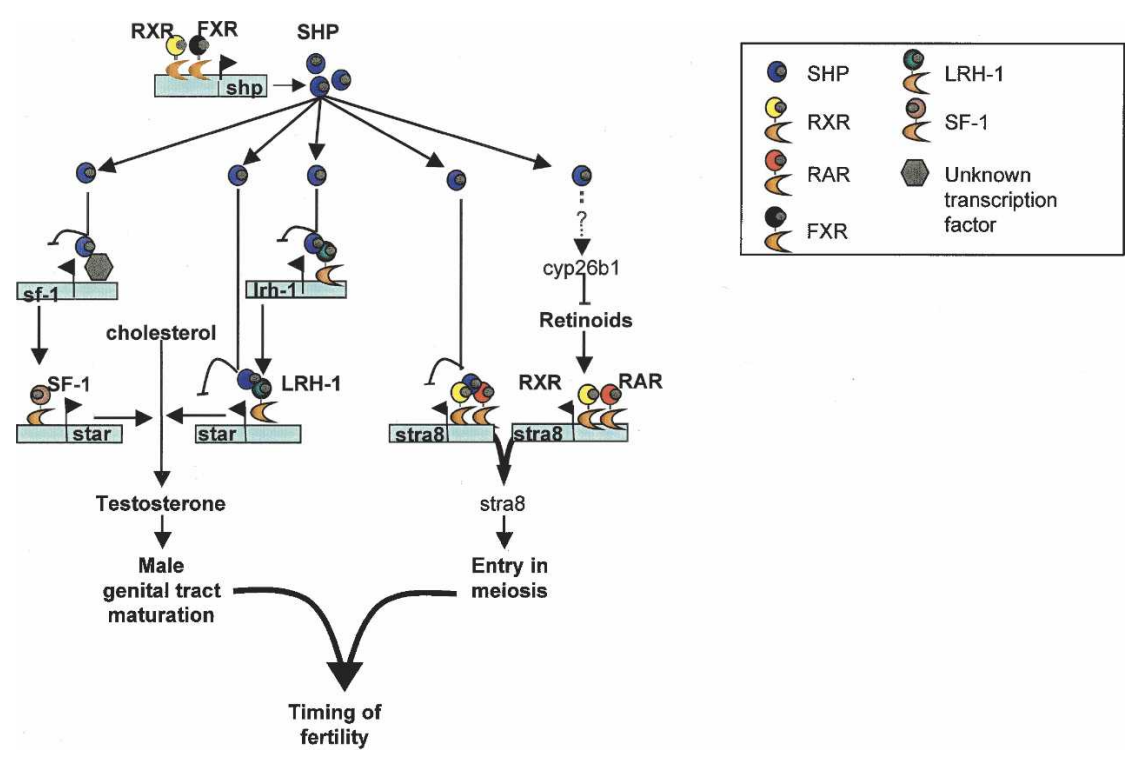
with 50 mg/kg GW4064 (a gift from M. Schwartz, Hoffman La Roche Pharmaceuticals Division, Basel, Switzerland) or vehicle (DMSO). Mice treated with GW4064 were sacrificed 6 or $12 \mathrm{~h}$ post-treatment. Animal protocols were approved by the regional ethics committee.

\section{$L M D$}

Cryosections ( $25 \mu \mathrm{m}$ thick) of the fresh-frozen testes were cut at $-16^{\circ} \mathrm{C}$, thaw-mounted onto PEN slides (Leica), stained with toluidine blue, and dehydrated in $70 \%$ and $100 \%$ ethanol followed by incubation for $1 \mathrm{~h}$ at $37^{\circ} \mathrm{C}$. The interstitial and tubular cells were obtained by LMD (Leica AS LMD) at $20 \times-40 \times$ magnification. Upon collection of $\sim 5000-10,000$ cells, total RNA was purified per the manufacturer's protocol (RNeasy microkit, Qiagen). The typical quantity of RNA purified was $\sim 40 \mathrm{ng}$, with a $28 \mathrm{~S}: 18 \mathrm{~S}$ rRNA ratio of 1.6:1.7.

\section{Histology}

Testes from mice at different ages were collected, formalinfixed, and embedded in parafin, and $6-\mu \mathrm{m}$ thick sections were prepared and stained with hematoxylin/eosin $(n=3-5$ animals per group). In each testis, the number of seminiferous tubules showing elongated spermatids was counted and reported as percentage of tubules counted.

\section{Hormone assays}

Testosterone concentrations were measured in the plasma or in frozen testis extracted with 10 vol of ethylacetate-isooctane (30:70, v:v). A commercial kit (ICN) was used for the assays. LH was determined on heparin-treated plasma by the Core Services of the University of Virginia Center for Research and Reproduction. RA concentration was measured in pooled testis of 20 $\mathrm{SHP}^{\mathrm{L} 2 / \mathrm{L} 2}$ and $\mathrm{SHP}^{\mathrm{L}-/ \mathrm{L}-}$ mice of $9 \mathrm{~d}$ of age by AS Vitas.

\section{Quantitative RT-PCR}

RNA from adrenals, pituitary, and laser-microdissected samples were isolated using the RNeasy kit (Qiagen). RNA from liver and testis were isolated using the Trizol method (Invitrogen Corporation). cDNA was synthesized from total RNA with the SuperScript II First-Strand Synthesis System (Life Technologies) and random hexamer primers. Quantitative RT-PCR measurements of individual cDNAs were performed using SYBR green dye to measure duplex DNA formation with the Roche LightCycler system. Results were normalized to $18 \mathrm{~S}$ rRNA levels. Sequences of the primers sets used are available at http://igbmc. fr/recherche/Dep_GPSN/Eq_JAuwe/Publi/Paper.html.

\section{Transient transfections}

The mouse star promoter luciferase reporter plasmid (X.J. Wang et al. 2003), containing DNA sequence between -966 and +18 base pairs (bp) from the transcription initiation site (p-966star/ Luc), was kindly provided by D. Stocco (Texas Tech University Health Sciences Center, Lubbock, TX). The pCMX expression vectors for mLRH-1 (Botrugno et al. 2004) and mSHP (Brendel et al. 2002) have been described. COS-1 cells were transfected with lipofectamin (Invitrogen) in 24-well plates. star promoter luciferase reporter construct (90 ng) was added in combination with the expression plasmid encoding for $\beta$-galactosidase (90 $\mathrm{ng}$ ), with empty pCMX or pCMX-mLRH-1 (20 ng) and increasing amounts of pCMX-mSHP (0-40 ng). The quantity of DNA was maintained constant by the addition of empty pCMX vector to a total amount of $240 \mathrm{ng}$ of DNA per well. Cells were harvested
$24 \mathrm{~h}$ later and assayed for luciferase and $\beta$-galactosidase activity. Luciferase values were normalized to $\beta$-galactosidase activity (Schoonjans et al. 1996).

F9 cells were transfected with lipofectamin (Invitrogen) in six-well plates. Increasing amounts of pCMX-mSHP $(0-1 \mu \mathrm{g})$ were added in combination with pCMX to maintain DNA quantity constant at $1 \mu \mathrm{g}$. After $24 \mathrm{~h}$ of transfection, cells were induced for $24 \mathrm{~h}$ with either vehicle or $10^{-7} \mathrm{M}$ of all-trans RA dissolved in DMSO, and further processed for mRNA analysis using Trizol extraction method.

\section{TUNEL analysis and Ki-67 staining}

Cryosections of testis $(10 \mu \mathrm{m})$ were fixed in PFA $4 \%$ for $10 \mathrm{~min}$, permeabilized with $0.1 \%$ Triton, $0.1 \%$ citrate solution in PBS for $2 \mathrm{~min}$ at $4^{\circ} \mathrm{C}$. TUNEL was performed with the in situ cell Death Detection kit (Roche Diagnostic). For the Ki-67 staining, sections were incubated overnight at $4^{\circ} \mathrm{C}$ with anti-Ki67 1/500 (Tebu-bio) then incubated $1 \mathrm{~h}$ at $21^{\circ} \mathrm{C}$ with a goat anti-rabbit secondary antibody labeled with Alexa 488 (Invitrogen). In each testis, at least 100 random seminiferous tubules were counted. Results are expressed as the number of TUNEL- or Ki-67-positive cells per 100 seminiferous tubules.

\section{ChIP assay}

ChIP was carried out following the protocol provided by the manufacturer (Upstate Biotechnology) using TM3 Leydig cells, F9 cells, and F9-RAR $\gamma^{-/-}$cells (kindly provided by Dr. C. Rochette-Egly, Institut de Génétique et de Biolgie Moléculaire et Cellulaire, Illkrich, France) as starting material. Sequences of the primer sets used to amplify the genomic DNA sequences of the star, cyp11a1, stra8, hoxa1, and $c d x 1$ genes are listed at http://igbmc.fr/recherche/Dep_GPSN/Eq_JAuwe/Publi/ Paper.html.

These primers were designed to amplify \pm 100 -bp fragments of DNA surrounding either the SF-1/LRH-1 or RAREs previously described on the promoters of the star (Caron et al. 1997), cyp11a1 (Ben-Zimra et al. 2002), stra8 (Giuili et al. 2002), hoxa1 (Langston and Gudas 1992), and $c d x 1$ (Houle et al. 2000) genes.

\section{Statistical analysis}

All data are expresssed as mean \pm SEM, except if stated otherwise. Student's $t$-test and analysis of variance (ANOVA) were performed to analyze differences between studied groups. Fisher's least-significant-difference method was used for multiple comparisons upon overall significant effect by ANOVA. Asterisk denotes significant difference between genotypes unless stated otherwise. A $P$ value of $<0.05$ was considered significant.

\section{Acknowledgments}

We thank Anne Caroff and Didier Hentsch for help in LMD; Cecile Rochette-Egly for the gift of F9 cells; Evi Denolet and Ludo Deboel for the enzymatic separation of interstitial and tubular testis cells; Tania Sorg, Abdel Ayadi, and Bénédicte Mascrez for establishing the SHP ${ }^{\mathrm{L} 2 / \mathrm{L} 2}$ mice at the Mouse Clinical Institute; and the members of J.A.'s laboratory for scientific discussions and support. We acknowledge support by grants of CNRS, INSERM, ULP, Hôpital Universitaire de Strasbourg, NIH (DK067320), AFM, FRM, and the EU (LSHM-CT-2004512013) and postdoctoral fellowships from the ARC to D.H.V. and the Serono Foundation to R.D.

\section{References}

Abel, M.H., Wootton, A.N., Wilkins, V., Huhtaniemi, I., Knight, P.G., and Charlton, H.M. 2000. The effect of a null mutation 
in the follicle-stimulating hormone receptor gene on mouse reproduction. Endocrinology 141: 1795-1803.

Argmann, C.A., Chambon, P., and Auwerx, J. 2005. Mouse phenogenomics: The fast track to 'systems metabolism.' Cell Metab. 2: 349-360.

Bakke, M., Zhao, L., Hanley, N.A., and Parker, K.L. 2001. SF-1: A critical mediator of steroidogenesis. Mol. Cell. Endocrinol. 171: $5-7$.

Baltus, A.E., Menke, D.B., Hu, Y.C., Goodheart, M.L., Carpenter, A.E., de Rooij, D.G., and Page, D.C. 2006. In germ cells of mouse embryonic ovaries, the decision to enter meiosis precedes premeiotic DNA replication. Nat. Genet. 38: 14301434.

Ben-Zimra, M., Koler, M., and Orly, J. 2002. Transcription of cholesterol side-chain cleavage cytochrome $\mathrm{P} 450$ in the placenta: Activating protein-2 assumes the role of steroidogenic factor- 1 by binding to an overlapping promoter element. Mol. Endocrinol. 16: 1864-1880.

Beuschlein, F., Keegan, C.E., Bavers, D.L., Mutch, C., Hutz, J.E., Shah, S., Ulrich-Lai, Y.M., Engeland, W.C., Jeffs, B., Jameson, J.L., et al. 2002. SF-1, DAX-1, and acd: Molecular determinants of adrenocortical growth and steroidogenesis. Endocr. Res. 28: 597-607.

Botrugno, O.A., Fayard, E., Annicotte, J.S., Haby, C., Brennan, T., Wendling, O., Tanaka, T., Kodama, T., Thomas, W., Auwerx, J., et al. 2004. Synergy between LRH-1 and $\beta$-catenin induces G1 cyclin-mediated cell proliferation. Mol. Cell 15: 499-509.

Bowles, J., Knight, D., Smith, C., Wilhelm, D., Richman, J., Mamiya, S., Yashiro, K., Chawengsaksophak, K., Wilson, M.J., Rossant, J., et al. 2006. Retinoid signaling determines germ cell fate in mice. Science 312: 596-600.

Brendel, C., Schoonjans, K., Botrugno, O.A., Treuter, E., and Auwerx, J. 2002. The small heterodimer partner interacts with the liver $\mathrm{X}$ receptor $\alpha$ and represses its transcriptional activity. Mol. Endocrinol. 16: 2065-2076.

Caron, K.M., Ikeda, Y., Soo, S.C., Stocco, D.M., Parker, K.L., and Clark, B.J. 1997. Characterization of the promoter region of the mouse gene encoding the steroidogenic acute regulatory protein. Mol. Endocrinol. 11: 138-147.

Chung, S. and Wolgemuth, D. 2004. Role of retinoid signaling in the regulation of spermatogenesis. Cytogenet. Genome Res. 105: 189-202.

Crawford, P.A., Dorn, C., Sadovsky, Y., and Milbrandt, J. 1998. Nuclear receptor DAX-1 recruits nuclear receptor corepressor N-CoR to steroidogenic factor 1. Mol. Cell. Biol. 5: 29492956.

Cummins, C.L., Volle, D.H., Zhang, Y., McDonald, J.G., Sion, B., Lefrancois-Martinez, A.M., Caira, F., Veyssiere, G., Mangelsdorf, D.J., and Lobaccaro, J.M. 2006. Liver X receptors regulate adrenal cholesterol balance. J. Clin. Invest. 116: 1902-1912.

De Gendt, K., Swinnen, J.V., Saunders, P.T., Schoonjans, L., Dewerchin, M., Devos, A., Tan, K., Atanassova, N., Claessens, F., Lecureuil, C., et al. 2004. A Sertoli cell-selective knockout of the androgen receptor causes spermatogenic arrest in meiosis. Proc. Natl. Acad. Sci. 101: 1327-1332.

Denolet, E., De Gendt, K., Allemeersch, J., Engelen, K., Marchal, K., Van Hummelen, P., Tan, K.A., Sharpe, R.M., Saunders, P.T., Swinnen, J.V., et al. 2006. The effect of a Sertoli cellselective knockout of the androgen receptor on testicular gene expression in prepubertal mice. Mol. Endocrinol. 20: 321-334.

Dierich, A., Sairam, M.R., Monaco, L., Fimia, G.M., Gansmuller, A., LeMeur, M., and Sassone-Corsi, P. 1998. Impairing follicle-stimulating hormone (FSH) signaling in vivo:
Targeted disruption of the FSH receptor leads to aberrant gametogenesis and hormonal imbalance. Proc. Natl. Acad. Sci. 95: 13612-13617.

Fayard, E., Auwerx, J., and Schoonjans, K. 2004. LRH-1: An orphan nuclear receptor involved in development, metabolism and steroidogenesis. Trends Cell Biol. 14: 250-260.

Francis, G.A., Fayard, E., Picard, F., and Auwerx, J. 2003 Nuclear receptors and the control of metabolism. Annu. Rev. Physiol. 65: 261-311.

Fu, M., Wang, C., Zhang, X., and Pestell, R. 2003. Nuclear receptor modifications and endocrine cell proliferation. J. Steroid Biochem. Mol. Biol. 85: 133-138.

Giguere, V. 1999. Orphan nuclear receptors: From gene to function. Endocr. Rev. 20: 689-725.

Giuili, G., Tomljenovic, A., Labrecque, N., Oulad-Abdelghani, M., Rassoulzadegan, M., and Cuzin, F. 2002. Murine spermatogonial stem cells: Targeted transgene expression and purification in an active state. EMBO Rep. 3: 753-759.

Goodwin, B., Jones, S.A., Price, R.R., Watson, M.A., McKee, D.D., Moore, L.B., Galardi, C., Wilson, J.G., Lewis, M.C., Roth, M.E., et al. 2000. A regulatory cascade of the nuclear receptors FXR, SHP-1, and LRH-1 represses bile acid biosynthesis. Mol. Cell 6: 517-526.

Hiort, O. 2002. Androgens and puberty. Best Pract. Res. Clin. Endocrinol. Metab. 16: 31-41.

Houle, M., Prinos, P., Iulianella, A., Bouchard, N., and Lohnes, D. 2000. Retinoic acid regulation of Cdxl: An indirect mechanism for retinoids and vertebral specification. Mol. Cell. Biol. 20: 6579-6586.

Houten, S.M., Watanabe, M., and Auwerx, J. 2006. Endocrine functions of bile acids. EMBO J. 25: 1419-1425.

Howard, W.R., Pospisil, J.A., Njolito, E., and Noonan, D.J. 2000. Catabolites of cholesterol synthesis pathways and forskolin as activators of the farnesoid X-activated nuclear receptor. Toxicol. Appl. Pharmacol. 163: 195-202.

Jeyasuria, P., Ikeda, Y., Jamin, S.P., Zhao, L., De Rooij, D.G., Themmen, A.P., Behringer, R.R., and Parker, K.L. 2004. Cellspecific knockout of steroidogenic factor 1 reveals its essential roles in gonadal function. Mol. Endocrinol. 7: $1610-1619$.

Johansson, L., Thomsen, J.S., Damdimopoulos, A.E., Spyrou, G., Gustafsson, J.A., and Treuter, E. 1999. The orphan nuclear receptor SHP inhibits agonist-dependent transcriptional activity of estrogen receptors ER $\alpha$ and ER $\beta$. J. Biol. Chem. 274: 345-353.

Kerr, T.A., Saeki, S., Schneider, M., Schaefer, K., Berdy, S., Redder, T., Shan, B., Russell, D.W., and Schwarz, M. 2002. Loss of nuclear receptor SHP impairs but does not eliminate negative feedback regulation of bile acid synthesis. Dev. Cell 2: $713-720$

Kim, J.W., Peng, N., Rainey, W.E., Carr, B.R., and Attia, G.R. 2004. Liver receptor homolog-1 regulates the expression of steroidogenic acute regulatory protein in human granulosa cells. J. Clin. Endocrinol. Metab. 89: 3042-3047.

Kim, J.W., Havelock, J.C., Carr, B.R., and Attia, G.R. 2005. The orphan nuclear receptor, liver receptor homolog-1, regulates cholesterol side-chain cleavage cytochrome p450 enzyme in human granulosa cells. J. Clin. Endocrinol. Metab. 90: 16781685.

Koubova, J., Menke, D.B., Zhou, Q., Capel, B., Griswold, M.D., and Page, D.C. 2006. Retinoic acid regulates sex-specific timing of meiotic initiation in mice. Proc. Natl. Acad. Sci. 103: 2474-2479.

Langston, A.W. and Gudas, L.J. 1992. Identification of a retinoic acid responsive enhancer $3^{\prime}$ of the murine homeobox gene Hox-1.6. Mech. Dev. 38: 217-227. 
Li, Y., Choi, M., Suino, K., Kovach, A., Daugherty, J., Kliewer, S.A., and $\mathrm{Xu}, \mathrm{H} . \mathrm{E} .2$ 2005. Structural and biochemical basis for selective repression of the orphan nuclear receptor liver receptor homolog 1 by small heterodimer partner. Proc. Natl. Acad. Sci. 102: 9505-9510.

Lu, T.T., Makishima, M., Repa, J.J., Schoonjans, K., Kerr, T.A., Auwerx, J., and Mangelsdorf, D.J. 2000. Molecular basis for feedback regulation of bile acid synthesis by nuclear receptors. Mol. Cell 6: 507-515.

Lu, T.T., Repa, J.J., and Mangelsdorf, D.J. 2001. Orphan nuclear receptors as eLiXiRs and FiXeRs of sterol metabolism. $J$. Biol. Chem. 276: 37735-37738.

Manna, P.R., Eubank, D.W., Lalli, E., Sassone-Corsi, P., and Stocco, D.M. 2003. Transcriptional regulation of the mouse steroidogenic acute regulatory protein gene by the cAMP response-element binding protein and steroidogenic factor 1 . J. Mol. Endocrinol. 30: 381-397.

Mueller, M., Cima, I., Noti, M., Fuhrer, A., Jakob, S., Dubuquoy, L., Schoonjans, K., and Brunner, T. 2006. The nuclear receptor LRH-1 critically regulates extra-adrenal glucocorticoid synthesis in the intestine. J. Exp. Med. 203: 2057-2062.

Murphy, L., Jeffcoate, I.A., and O'Shaughnessy, P.J. 1994. Abnormal Leydig cell development at puberty in the androgenresistant Tfm mouse. Endocrinology 135: 1372-1377.

Pezzi, V., Sirianni, R., Chimento, A., Maggiolini, M., Bourguiba, S., Delalande, C., Carreau, S., Ando, S., Simpson, E.R., and Clyne, C.D. 2004. Differential expression of steroidogenic factor-1/adrenal 4 binding protein and liver receptor homo$\log -1$ (LRH-1)/fetoprotein transcription factor in the rat testis: LRH-1 as a potential regulator of testicular aromatase expression. Endocrinology 145: 2186-2196.

Russell, D.W. 1999. Nuclear orphan receptors control cholesterol catabolism. Cell 97: 539-542.

Schoonjans, K., Peinado-Onsurbe, J., Lefebvre, A.M., Heyman, R.A., Briggs, M., Deeb, S., Staels, B., and Auwerx, J. 1996. $\operatorname{PPAR} \alpha$ and PPAR $\gamma$ activators direct a distinct tissue-specific transcriptional response via a PPRE in the lipoprotein lipase gene. $E M B O ~ J$. 15: 5336-5348.

Seol, W., Choi, H.S., and Moore, D.D. 1996. An orphan nuclear hormone receptor that lacks a DNA binding domain and heterodimerizes with other receptors. Science 272: 1336-1339.

Shibata, H., Kurihara, I., Kobayashi, S., Yokota, K., Suda, N., Saito, I., and Saruta, T. 2003. Regulation of differential COUP-TF-coregulator interactions in adrenal cortical steroidogenesis. J. Steroid Biochem. Mol. Biol. 85: 449-456.

Sinal, C.J., Tohkin, M., Miyata, M., Ward, J.M., Lambert, G., and Gonzalez, F.J. 2000. Targeted disruption of the nuclear receptor FXR/BAR impairs bile acid and lipid homeostasis. Cell 102: 731-744.

Wang, Z.J., Jeffs, B., Ito, M., Achermann, J.C., Yu, R.N., Hales, D.B., and Jameson, J.L. 2001. Aromatase (Cyp19) expression is up-regulated by targeted disruption of Dax1. Proc. Natl. Acad. Sci. 98: 7988-7993.

Wang, L., Lee, Y.K., Bundman, D., Han, Y., Thevananther, S., Kim, C.S., Chua, S.S., Wei, P., Heyman, R.A., Karin, M., et al. 2002. Redundant pathways for negative feedback regulation of bile acid production. Dev. Cell 2: 721-731.

Wang, L., Han, Y., Kim, C.S., Lee, Y.K., and Moore, D.D. 2003. Resistance of SHP-null mice to bile acid-induced liver damage. J. Biol. Chem. 278: 44475-44481.

Wang, X.J., Dyson, M.T., Jo, Y., Eubank, D.W., and Stocco, D.M. 2003. Involvement of 5-lipoxygenase metabolites of arachidonic acid in cyclic AMP-stimulated steroidogenesis and steroidogenic acute regulatory protein gene expression. J. Steroid Biochem. Mol. Biol. 85: 159-166.
Wang, S., Lai, K., Moy, F.J., Bhat, A., Hartman, H.B., and Evans, M.J. 2006. The nuclear hormone receptor farnesoid X receptor (FXR) is activated by androsterone. Endocrinology 147: 4025-4033.

Weinbauer, G.F., Aslam, H., Krishnamurthy, H., Brinkworth, M.H., Einspanier, A., and Hodges, J.K. 2001. Quantitative analysis of spermatogenesis and apoptosis in the common marmoset (Callithrix jacchus) reveals high rates of spermatogonial turnover and high spermatogenic efficiency. Biol. Reprod. 64: 120-126.

Wilson, J.D., Leihy, M.W., Shaw, G., and Renfree, M.B. 2002. Androgen physiology: Unsolved problems at the millennium. Mol. Cell. Endocrinol. 198: 1-5.

Wolgemuth, D.J., Laurion, E., and Lele, K.M. 2002. Regulation of the mitotic and meiotic cell cycles in the male germ line. Recent Prog. Horm. Res. 57: 75-101. 


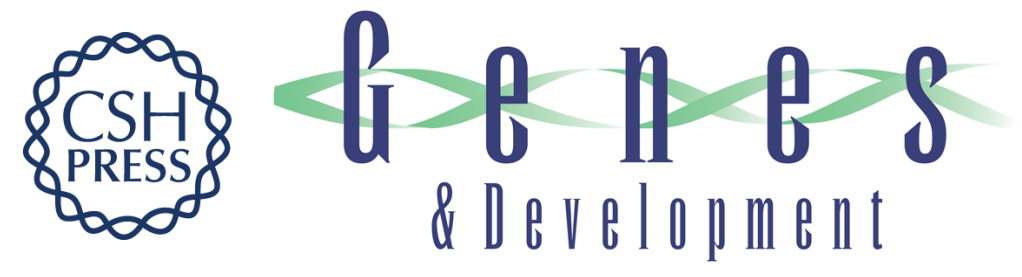

\section{The small heterodimer partner is a gonadal gatekeeper of sexual maturation in male mice}

David H. Volle, Rajesha Duggavathi, Benjamin C. Magnier, et al.

Genes Dev. 2007, 21:

Access the most recent version at doi:10.1101/gad.409307

Supplemental http://genesdev.cshlp.org/content/suppl/2007/02/08/21.3.303.DC1
Material

References This article cites 52 articles, 13 of which can be accessed free at: http://genesdev.cshlp.org/content/21/3/303.full.html\#ref-list-1

License

Email Alerting Receive free email alerts when new articles cite this article - sign up in the box at the top Service right corner of the article or click here.

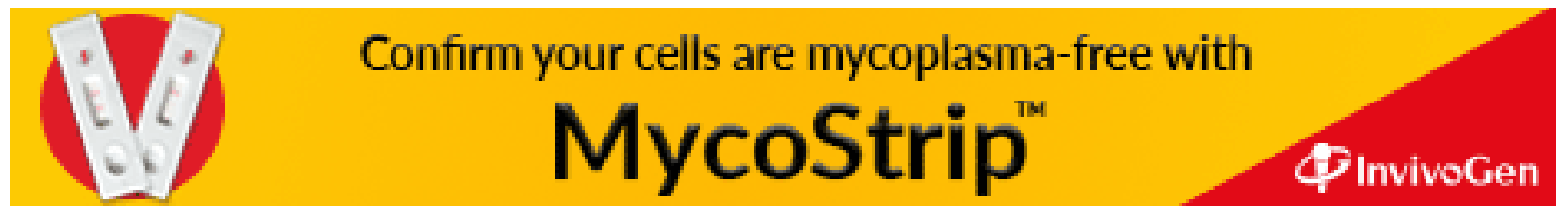

